\title{
Global Rangeland Primary Production and Its Consumption by Livestock in 2000-2010
}

\author{
Julie Wolf $1,2, *$, Min Chen ${ }^{1,3,4}$ and Ghassem R. Asrar 1,5 \\ 1 Joint Global Change Research Institute, 5825 University Research Court, Suite 3500, \\ College Park, MD 20740, USA; mchen392@wisc.edu (M.C.); gasrar@usra.edu (G.R.A.) \\ 2 USDA-ARS, Adaptive Cropping Systems Laboratory, 10300 Baltimore Ave., Building 001, Room. 342, \\ BARC-WEST, Beltsville, MD 20705, USA \\ 3 Department of Forest and Wildlife Ecology, University of Wisconsin-Madison, 1630 Linden Drive, \\ Madison, WI 53706, USA \\ 4 Nelson Institute Center for Climatic Research, University of Wisconsin-Madison, 1225 W. Dayton St., \\ Madison, WI 53706, USA \\ 5 Universities Space Research Association, 7178 Columbia Gateway Drive, Columbia, MD 21046, USA \\ * Correspondence: julie.wolf2@usda.gov; Tel.: +1-301-504-5527; Fax: +1-301-504-5823
}

check for updates

Citation: Wolf, J.; Chen, M.; Asrar, G.R. Global Rangeland Primary Production and Its Consumption by Livestock in 2000-2010. Remote Sens. 2021, 13, 3430. https://doi.org/ $10.3390 /$ rs13173430

Academic Editor:

Palacios-Orueta Alicia

Received: 21 June 2021

Accepted: 25 August 2021

Published: 29 August 2021

Publisher's Note: MDPI stays neutral with regard to jurisdictional claims in published maps and institutional affiliations.

Copyright: (c) 2021 by the authors. Licensee MDPI, Basel, Switzerland. This article is an open access article distributed under the terms and conditions of the Creative Commons Attribution (CC BY) license (https:/ / creativecommons.org/licenses/by/ $4.0 /)$.

\begin{abstract}
Livestock grazing occupies ca. 25\% of global ice-free land, removing large quantities of carbon (C) from global rangelands (here, including grass- and shrublands). The proportion of total livestock intake that is supplied by grazing (GP) is estimated at $>50 \%$, larger than the proportion from crop- and byproduct-derived fodders. Both rangeland productivity and its consumption through grazing are difficult to quantify, as is grazing intensity (GI), the proportion of annual aboveground net primary productivity (ANPP) removed from rangelands by grazing livestock. We develop national or sub-national level estimates of GI and GP for 2000-2010, using remote sensing products, inventory data, and model simulations, and accounting for recent changes in livestock intake, fodder losses and waste, and national cropland use intensities. Over the 11 study years, multi-model average global rangeland ANPP varied between the values of $13.0 \mathrm{Pg} \mathrm{C}$ in 2002 and $13.96 \mathrm{Pg} \mathrm{C}$ in 2000. The global requirement for grazing intake increased monotonically by $18 \%$, from 1.54 in 2000 to $1.82 \mathrm{Pg} C$ in 2010. Although total global rangeland ANPP is roughly an order of magnitude larger than grazing demand, much of this total ANPP is unavailable for grazing, and national or sub-national deficits between intake requirements and available rangeland ANPP occurred in each year, totaling $36.6 \mathrm{Tg} \mathrm{C}$ ( $2.4 \%$ of total grazing intake requirement) in 2000 , and an unprecedented $77.8 \mathrm{Tg} \mathrm{C}$ ( $4.3 \%$ of global grazing intake requirement) in 2010. After accounting for these deficits, global average GI ranged from $10.7 \%$ in 2000 to $12.6 \%$ in 2009 and 2010 . The annually increasing grazing deficits suggest that rangelands are under significant pressure to accommodate rising grazing demand. Greater focus on observing, understanding, and managing the role of rangelands in feeding livestock, providing ecosystem services, and as part of the global C cycle, is warranted.
\end{abstract}

Keywords: rangeland ANPP; livestock grazing; grazing intensity; livestock feed sources; MODIS; global carbon cycle

\section{Introduction}

Currently, the global biomass of mammalian livestock is $67 \%$ larger than that of humans, $1329 \%$ larger than that of all wild mammals, and 318\% larger than total mammalian biomass that was supported on Earth 100,000 years ago [1]. The increase to current dominance has been possible via consumption of correspondingly large proportions of annual terrestrial net primary productivity (NPP). Globally, ca. 35\% of all primary crop harvests and ca. $24 \%$ of all crop residues are consumed by livestock [2]. In addition to these sources of fodder, global livestock currently graze on ca. $24 \%$ of global ice-free land area, compared to ca. $2 \%$ before the start of the industrial revolution [3]. The livestock sector produces 
small quantities of high-quality, protein- and iron-rich food, from very large quantities of edible and inedible crop products and inedible aboveground NPP (ANPP) grazed from global rangelands [4]. Estimates for 2011 indicate that the global livestock sector produced ca. $56 \mathrm{Tg}$ C of milk and eggs and $82 \mathrm{Tg} \mathrm{C}$ in meat, and consumed $2826 \mathrm{Tg} \mathrm{C}$ of total feed, of which $1650 \mathrm{Tg} C$ was supplied by grazing [2]. Most of the consumed carbon (C) is rapidly returned to the atmosphere as carbon dioxide $\left(\mathrm{CO}_{2}\right)$ or methane [2]. At the global level, mean ecosystem C turnover time was $13.5 \%$ faster in the 2000s than it was before the industrial revolution [5]; Wu and coauthors find land use change (LUC) to be the main cause of this increase. LUC occurs primarily due to increases in the extent of pastures and croplands $[6,7]$. Therefore, the livestock sector acts as a short-circuit of the biologic $\mathrm{C}$ cycle at an increasingly massive scale. Because of their magnitude and uncertainty, C fluxes associated with livestock consumption of forage and fodder consumption must be better documented so that they can be represented in Earth System Models [8].

Recent decades have seen rapid changes in how and where livestock are raised [9]. Between the years 2000 and 2010, total cattle populations increased by $28.4 \%$ in Africa, $15.6 \%$ in Central and South America, and 6.8\% in South Asia, but decreased by $4.2 \%$ in North America, 15.9\% in Europe, and 17.2\% in East and Southeast Asia [10]. The size, growth, and productivity of several livestock species have been increased through genetic improvements, feed optimization, and use of preventative and growth-promoting feed additives [11-13]; therefore some population decreases are due to increasing productivity [14]. However, global sources of animal products have also shifted, for example increasing exports from South America to China and other nations and regions [15]. These changes are likely to impact supply of and demand for rangeland ANPP. Large-scale livestock operations, where housed animals consume only delivered crop-based fodders, have replaced pastoral livestock husbandry to varying degrees [16,17]. Along with increasing livestock body size and productivity, total numbers of meat and dairy cattle, pigs, goats, and chickens have increased since 1990 [10]. Over this time period, however, the estimated proportion of total livestock intake supplied by grazing (GP) has remained between 50 and $60 \%[4,18,19]$, necessitating increasing quantities of grazed rangeland NPP.

Because the most productive lands tend to be used for crops, grazing often occurs on less-productive drylands and grasslands with more variable or extreme climates [20]. These grazing lands may produce feed of lower quality and quantity, leading to higher methane emissions intensities, slower animal growth rates, and lower feed use efficiency [21]. In less productive rangelands, the removal of large quantities of plant biomass by grazers often leads to land degradation [20], making ANPP more unpredictable and sensitive to interannual variability.Livestock density and pasture management also interact with fluctuations in climate to impact primary and secondary productivity of rangelands [22,23]. These complex interactions, along with uncertain effects of climate change on rangelands [24], require more detailed study across multiple years of climate variability.

Global croplands are also under increasing pressure to supply food, feed, bioenergy crops, and ecosystem services such as soil C storage. Along with climatic, economic, or political disruption, this pressure can make crop-based livestock feeds more scarce or expensive. For example, crop residues are increasingly left on fields or processed into biofuels, decreasing their availability as fodder [25]. At the same time, increasing production of bioethanol generates large quantities of byproduct feeds (e.g., dried distillers grains with solubles) that were not widely available before the mid-2000s [26,27]. To sustainably manage grazing, there is a need for reliable estimates of both how much ANPP is produced and how much is currently removed by grazing livestock, despite the difficulties imposed by variations in quality, availability, and demand for fodder and grazed forage over time.

Herrero et al. [28] developed a global, gridded dataset of grass biomass consumption by livestock for the year 2000. They estimated the total livestock intake requirement for that year at $4.7 \mathrm{Pg}$ of dry matter, of which $2.4 \mathrm{Pg}(48 \%)$ was grass from silage and/or grazing. Chang et al. [29] used this dataset, along with modeled (ORCHIDEE) and in situ 
measurements of rangeland ANPP, to map rangeland management and grazing intensity (GI, the proportion of annual aboveground net primary productivity (ANPP) removed by grazing livestock). While these authors modeled multiple years of ANPP, they used livestock grazing requirements from the year 2000. They found that $16 \%$ of the estimated $2.4 \mathrm{Pg}$ [28] of the grass dry matter intake requirement could not be fulfilled by their modelled ANPP, resulting in a global grazing deficit of $0.38 \mathrm{Pg}$ of dry matter, with the largest deficiencies in Southern Asia, East Asia, and North Africa [29].

Fetzel et al. [30] described uncertainties associated with rangeland grazing by comparing multiple models and satellite-based estimates of rangeland ANPP with multiple estimates of grazing demand, using data for the year 2000. In at least one of the 96 simulations these authors generated, GI greater than $100 \%$ of ANPP (which is not possible, and implies grazing deficits) was required on $27 \%$ of global grazing areas, concentrated in the regions described by Chang et al. [29], as well as in parts of Western Europe. However, upon re-evaluating potential GI via consideration of seasonal quantities of standing dead plant biomass, Fetzel et al. [31] concluded that more biomass could be grazed in many areas of the globe. This conclusion is hard to reconcile with the grazing deficits documented previously [32].

While body mass and feed intake requirements have recently been revised upwards for beef and dairy cattle in most but not all world regions [2], reported annual quantities of market feeds, residues, hay crops and other fodders have not changed. Therefore, more intake must have come from grazing to meet overall intake requirements. If deficits like found by Chang et al. [29] and Fetzel et al. [30] occur only in a rare year or two, e.g., during a short drought period, livestock might be underweight, perish, or be slaughtered early. Longer periods of drought may also occur, for example, the 1999-2013 cold phase of the Pacific Decadal Oscillation (PDO), which has been shown to cause lower mean annual ANPP and higher interannual ANPP variability in Western US rangelands [23,33]. If the livestock sector cannot adjust to multi-year perturbations like this, deficits in livestock intake would continue over many years, which would be unsustainable for livestock operations. Therefore, if such deficits are detected year after year in a given nation or region, it might be reasonable to suspect one or more errors: estimates of ANPP may be too low; the area assigned to rangeland may be incomplete; estimates of livestock populations, body size, and/or feed intake may be too large; and/or sources of fodder may be underestimated or missing. Alternatively, frequent years with high GI or grazing deficits may in fact be an accurate finding. Because single-year assessments may reflect unique weather or other conditions in that year, or the beginning of a pattern to which livestock operations have not yet responded, we set out to compare grazing requirements and ANPP over multiple years with detailed data. Unlike previous studies, we account for (i) changing livestock numbers, size, and intake requirements over the study period, (ii) annual fluctuations in harvested cropland areas, (iii) national differences in cropland use intensity (i.e., multiple crops per year from the same harvested area), and (iv) annually reported fodder availability, intrinsically including effects of crop yields, changing grain prices, demand from bioenergy and other sectors, and other factors. Our goals were to further explore reported incidences of GI $>100 \%$ of ANPP found in multiple reports, to look for temporal trends in use of global rangeland (grassland and shrubland) ANPP, and to better understand the extent, if any, to which grazing could be sustainably expanded.

\section{Methods}

\subsection{General}

Our general strategy for livestock grazing demand is to follow the "grazing gap" method $[19,30]$. In this method, total livestock intake requirements and available fodder are quantified or estimated, and the difference or 'gap' between the two is assumed to be made up by grazing intake. We use 11 years of annual livestock intake requirement estimates resulting from revision of, and transition from, IPCC 2006 Guidelines activity data [34] to revised regional values for livestock characteristics (e.g., weight, productivity, intake 
requirements) and management (e.g., diet quality, housed vs. free ranging) [2]. We amend this revised data with detailed annual estimates of fodder availability [4] to estimate annual grazing requirements based on the difference or 'gap' between total intake requirements and available fodder. We then use national estimates of multi-cropping [35] to adjust annual harvested cropland area [10], and harmonize the extent of land available for grazing animals to these annually adjusted crop harvest areas. We estimate grass- and shrubland ANPP available for grazing from the Inter-Sectoral Impact Model Intercomparison Project Phase 2a (ISIMIP2a), which provides an ensemble of global terrestrial biosphere model (TBM) simulations for the study period at $0.5^{\circ}$ resolution (see details in Section Rangeland extent, NPP, and ANPP below).

Livestock populations and thus total intake requirements are at the national or subnational (for ten large nations: Argentina, Brazil, Canada, Chile, China, India, Kazakhstan, Mexico, Russian Federation, and United States, for which we had state- or province-level livestock population distributions [4]). Quantities of annually available fodder, however, are only reported at the national level (i.e., we have no sub-national information on fodder distribution). Grid scale rangeland ANPP quantities from ISIMIP2a models were summed to the national or subnational (to match the same ten large nations) level. For nations with no subnational information, this leads to a straightforward subtraction of fodder quantities from total intake requirements in each year of the study, and subsequent comparison to that year's total rangeland ANPP within that nation. For nations with subnational livestock population information, fodder and forage were allocated among states/provinces based on known states/provinces with higher grazing levels, availability of ANPP, and/or uniformly, as described below for each of the nations with sub-national livestock populations. We used an iterative approach to arrive at and state level distributions that best met grazing requirements.

\subsection{Livestock Populations and Total Intake Requirements}

Livestock populations and intake requirements are estimated following methodology used by Wolf et al. [2]. Annual national livestock populations of meat and milk-producing cattle, meat and milk-producing buffaloes, meat and egg-laying chickens, swine, sheep, turkeys, ducks, geese and guinea fowl, goats, horses, mules, asses, camels, and other camelids (i.e., llamas and alpacas) were compiled for years 2000-2010 from FAO [10]. Annual producing populations of egg-laying chickens and milk-producing cattle and buffalo were subtracted from conspecific total populations to derive the numbers raised for meat production. Dairy cattle livestock populations include only milk-producing mature dairy cows; calves, heifers, breeding steers, and any other dairy cattle 'replacements' are categorized with meat/other cattle. For nine large countries (Argentina, Brazil, Canada, Chile, China, India, Kazakhstan, Mexico, and the Russian Federation), state- or provincelevel proportions of national livestock populations were compiled for available years between 2000-2010 [36], and used to improve the spatial distribution of inventory data. For the United States, livestock populations were refined to the state level using National Agricultural Statistical Service Census and Survey data [37]. Livestock in all other nations of the world are constrained at the national level only. The mismatch between fodder and livestock population distributions in the ten large nations is a potential source of error in those countries that is not present in smaller nations without sub-national livestock distributions. However, we believe that assigning fodder to states in these large countries based on known information (see below) is better than uniformly distributing fodder sources to all states, given that some states will have more or less abundant grazing resources (e.g., states with dense cropland and/or human populations vs. more arid states with large rangeland areas, as found among different parts of China and the US).

Annual per-animal dry weight feed intake were taken from Wolf et al. [2]. In that effort, annual intakes for meat cattle, dairy cows, and swine, in all global regions, were estimated based on literature review in conjunction with simple energy intake models based on animal weight presented in IPCC 2006 [34], or, where no new information was available, follow IPCC 2006 [34] default values. Livestock total dry matter intakes were 
assumed to be $44 \% \mathrm{C}$ by weight, in order to convert total intake requirements to quantities of $C$. This value is expected to be close to the $C$ content of grazed biomass and many hay crops, residue, and soybean cake feed sources [4,38], but may be higher than the C content fresh vegetal (non-grain) feeds, and lower than the $C$ content of whole grain and oilseed feeds [4]. This could lead to an underestimation of total livestock intake $C$ requirement when diets include a large proportion of grain and/or oilseed feeds.

\subsection{Annual Fodder Stocks per Nation, Estimation of Fodder Losses and Waste, and Fodder Intake}

Available fodder is derived based on the methodology derived by Wolf et al. [4]. For purposes of estimating amounts of grazing, total livestock feed intake was qualified as fodder (i.e., all biomass harvested and removed by humans from croplands or pasture) or forage (i.e., all biomass grazed or scavenged by livestock from rangeland areas not reclassified as harvested cropland in the year of interest, see Rangeland Extent, NPP, and ANPP Section below). Fodder is further subdivided into (i) market feed items derived from primary harvests (e.g., grains, crop byproducts), (ii) hay and fodder crops (e.g., harvested quantities of alfalfa, clovers, grasses, corn and sorghum silage), and (iii) crop residue feed, consisting of crop residue collected from the field for livestock feed.

Annual national quantities of all market feed items available, including imports, are reported by FAO [10]. These quantities were converted into mass of $C$ using published item-specific fractional dry weight and C contents [4]. Hay and fodder crops (e.g., harvested quantities of alfalfa, clovers, grasses, corn and sorghum silage) were reported by FAO [10] for the years of the study; these included maize, alfalfa, and other grains, grasses, legumes, roots, and vegetables denoted as produced for forage and/or silage; very high values for "Pumpkins" were deleted in each year. Crop residue feed quantities were estimated by applying crop-specific regional percentages of residues collected for feed given by Krausmann et al. [19] to crop- and country-specific estimates of annual residue production [4].

We could not find any other studies of livestock intake that explicitly exclude estimated fodder losses and waste, which we find to be sizable. Before summing the sources of fodder in each nation, we first estimated and subtracted the amounts lost or wasted before consumption by livestock. First, we subtracted a conservative estimate of $2.5 \%$ on-field losses to all hay, haylage, silage, and other FAO-reported fodder crop harvests (item (ii) in the paragraph above), to account for losses during cutting, mowing, on-field drying, gathering, and/or baling [39]. While larger total losses (e.g., $\geq 12 \%$ ) are reported over all stages of hay or silage harvest [40-42] the processes and equipment employed vary greatly, and some of these losses may occur during stages after harvest quantities are reported. Second, to account for fodder losses during sale and/or transfer, storage, delivery, and feeding, we subtracted an additional 17\% from quantities of all hay, haylage, silage, and crop residues collected for fodder and we subtracted an additional 10\% from all reported "market feeds" including primary crop, grain and byproduct feed items [43-47].

After these quantities of losses and waste were subtracted, total remaining fodder sources in each nation and year were summed and subtracted from that year's total livestock intake requirements to derive annual, national estimates of grazing intake requirements. In some nations and years, even after subtracting estimated fodder losses and waste, more fodder was available than required to meet total livestock intake requirements, and no grazing intake was required (although this may not mean that no grazing occurred). For purposes of accounting, in those cases, the extra quantities were eliminated first from estimated/reported crop residue for feed; and if there was still an overage, reductions were taken from reported hay crops as well, until amounts of available fodder equaled total livestock intake requirements. The countries with at least one year of this condition between 2000 and 2010 were: Czech Republic, Germany, Egypt, Hungary, Israel, Japan, Sri Lanka, Montenegro, Malaysia, and the Russian Federation. 


\subsection{Rangeland Extent, NPP, and ANPP}

Available rangeland extent, including grassland and shrublands, was estimated with a land cover spatial allocation model, Demeter [48,49], by expanding or contracting annual cropland extent based on the land cover product [50] of the MODerate resolution Imaging Spectroradiometer (MODIS) to accommodate annual harvested cropland areas, excluding fallow. Annual harvested cropland area was adjusted for differing degrees of double- or multi-cropping, by using national numbers given by Ray and Foley [35]. This was done by summing up the total area of harvested croplands in each nation and year of the study, for all crops included in Wolf et al. [4]. In nations with cropland harvest frequency $>1.0$ (Table 1), the total harvested cropland area was divided by the cropland harvest frequency. Only the harvested areas of nations with cropland harvest frequency greater than 1 were modified. Land area classified as cropland in MODIS was expanded or contracted to match annual harvested area, with surplus or deficit area added to or taken from land classified as grassland. This adjustment reduces total annual harvested area in nations where multiple crops per year are harvested, and results in more area that may be used for grazing.

Table 1. Nations with cropland harvest frequency greater than one.

\begin{tabular}{|c|c|}
\hline Nation & Cropland Harvest Frequency $^{a}$ \\
\hline Argentina & 1.02 \\
\hline Bangladesh & 1.67 \\
\hline Belgium & 1.20 \\
\hline Brunei & 2.30 \\
\hline Burkina Faso & 1.04 \\
\hline China & 1.29 \\
\hline Colombia & 1.04 \\
\hline North Korea & 1.09 \\
\hline Denmark & 1.08 \\
\hline Egypt & 1.75 \\
\hline Gambia & 1.03 \\
\hline Germany & 1.66 \\
\hline Hungary & 1.03 \\
\hline India & 1.14 \\
\hline Laos & 1.01 \\
\hline Malawi & 1.03 \\
\hline Myanmar & 1.45 \\
\hline Nepal & 1.91 \\
\hline Netherlands & 1.21 \\
\hline Nigeria & 1.16 \\
\hline Papua New Guinea & 1.08 \\
\hline Paraguay & 1.75 \\
\hline Philippines & 1.32 \\
\hline
\end{tabular}


Table 1. Cont.

\begin{tabular}{cc}
\hline Nation & Cropland Harvest Frequency $^{\mathbf{a}}$ \\
\hline South Korea & 1.03 \\
\hline Rwanda & 1.28 \\
\hline Sri Lanka & 1.04 \\
\hline Tajikistan & 1.09 \\
\hline United Arab Emirates & 1.35 \\
\hline Vietnam & 1.39 \\
\hline
\end{tabular}

${ }^{a}$ As reported by Ray and Foley [35].

Available rangeland NPP quantities were based on an ensemble of eight TBMs that joined the ISIMIP2a experiments, including CARAIB, DLEM, JULES, LPJmL, LPJ-GUESS, ORICHIDEE, VEGAS, and VISIT [51], as well as the Net Primary Production Product from MODIS (MOD17). Under the ISIMIP2a protocol, the models were driven by the common historical forcings, including time-variant $\mathrm{CO}_{2}$ concentrations, climate from Global Soil Wetness Project 3 (GSWP3), and land use change from the History Database of the Global Environment (HYDE) [3]. ANPP was estimated as $60 \%$ of total NPP [30] from the ensemble mean of the eight models in rangeland areas. We consider $64 \%$ of ANPP as an upper limit to sustainable annual consumption [52,53], although truly sustainable rates over multiple years are likely to be much lower.

\subsection{Sub-National Allocation of Fodder and Forage Intake}

The datasets assembled for this study, described above, allowed us to estimate: (a) national quantities of annual fodder, (b) national or sub-national rangeland NPP, and (c) national or sub-national total livestock intake requirements. In our analysis, national fodder quantities could be allocated to sub-national areas (e.g., states and provinces) freely, while sub-national estimates of livestock intake requirements and ANPP could not be moved. This is because (i) ANPP is grazed in the location it grew, and (ii) sub-national livestock populations already account for movement of livestock among states. Therefore, if a state has excess unconsumed rangeland ANPP after meeting even 100\% of its own livestock intake requirement, its rangeland ANPP cannot be used to satisfy intake needs in other states; mown and transferred ANPP would be counted as harvested fodder which is already part of our computations. A nation may have large amounts of underutilized rangeland ANPP, e.g., in remote areas, and also have high localized GIs and unmet intake requirements, e.g., in dense urbanized or cropped areas, in a given year. For example, in the U.S., a weaned calf may start out consuming $100 \%$ grazing intake in a western state like New Mexico, and then may move to Texas to be finished on 100\% feed; we consider that our sub-national livestock populations have already accounted for these moves and do not allow transfer of grazing intake to other states.

There are two different conditions to meet when allocating grazing among subnational states, provinces or other large administrative divisions: neither GP (the percent of total livestock intake that is provided by grazing) nor GI (the percent of total ANPP that is consumed by grazing) can exceed $100 \%$. To allocate fodder realistically, different strategies were tailored for the ten large nations with subnational information as described below:

Argentina, Brazil, Canada, and Chile: Annual grazing levels in each state were assigned the lesser of (a) $99 \%$ GP or (b) a nationally-uniform GI, resulting in GP $<99 \%$. This results in most states having $99 \%$ GP, with GP in a few states where total intake requirements are large relative to their rangeland ANPP allocated relatively more fodder to meet requirements.

China: Many western provinces have extensive grasslands and grazing, while many eastern ones have very little ANPP available for grazing [54]. Therefore, in provinces where total livestock intake requirements were much lower than available ANPP, grazing was 
assigned at $100 \%$ GP. Provinces with grazing intake requirements larger than total ANPP were assigned grazing up to a nationally-uniform GI that changed annually to meet total requirements. These GI levels did not exceed 64\% of ANPP except in 2007 and 2009 where this level could not provide sufficient intake.

India: According to Roy and Singh [55], the states Arunachal Pradesh, Gujarat, Himalchal Pradesh, Jammu and Kashmir, Maharashtra, Rajasthan, Sikkim, Uttarakhand, and West Benghal have more extensive grazing area than the others. In these states, if the total livestock intake requirement was less than $83 \%$ of rangeland ANPP (corresponding to 50\% of total NPP) in a given year, grazing intake was assigned at 99.9\% GP. In all other states, as well as in these high-grazing states if their livestock intake requirement was larger than $83 \%$ of their ANPP, grazing was assigned at a nationally-uniform GI. This results in some states with low GI and others with unsustainable but not impossible ( $>100 \%)$ GI levels.

Kazakhstan: States were assigned grazing as the smaller of: $99 \%$ GP or a nationallyuniform GI 1 to $7 \%$.

United States: Certain western states have larger areas of rangeland per grazing animal in 2007, as calculated from numbers of total cattle and cattle on feed [37] and pasture and rangeland extent [56]. These states are Alaska, Arizona, Colorado, Montana, Nevada, New Mexico, Oregon, Utah, and Wyoming, with $\geq 7.2$ hectares of grazing area per head. While Texas had the largest rangeland area of all US states, it also had the largest grazing cattle population, and thus the area of rangeland per animal was similar to the remaining states where $\leq 3.8$ hectares per head were available. In the states with more extensive rangeland per grazing animal, if the total livestock intake requirement was less than $58.3 \%$ of ANPP (35\% of total NPP), then the state's grazing was assigned at a rate of $99 \%$ GP. In the other states, as well as in these high-grazing states if their livestock intake requirement was larger than 58.3\% of their ANPP, grazing was assigned at the lesser of $99 \%$ GP or a nationally-uniform GI was assigned to grazing.

Mexico: According to Bohn et al. [57], the states of Aguascalientes, Chihuahua, Durango, Guanajuato, San Luis Potosi, Sonora, and Zacatecas contain the most extensive rangelands. In these states, if the total livestock intake requirement was less than 58.3\% of ANPP (35\% of total NPP), then the state's grazing was assigned at a rate of 99\% GP. In the other states, as well as in these high-grazing states if their livestock intake requirement was larger than $58.3 \%$ of their ANPP, grazing was assigned at the lesser of $99 \%$ GP or a nationally-uniform GI was assigned to grazing.

Russian Federation: In this nation, very low or no amounts of grazing were needed in any year due to very large amounts of available fodder. A uniform small GI was assigned to all states in grazing in years when GP > $0 \%$.

\subsection{Sub-National Allocation of Fodder and Forage Intake}

Annual quantities of available C contained in rangeland ANPP and consumed by grazing livestock were summed to regional levels according to the groupings listed in Table 2 . In cases where impossible ( $>100 \%$ of ANPP) GI would be needed to meet national livestock requirements, the amount of ANPP consumed was capped at $100 \%$ of ANPP and the amount of intake $\mathrm{C}$ missing was recorded as a grazing deficit. This allows for regional GIs to be calculated accurately. 
Table 2. Regional divisions in different continents used for regional analysis.

\begin{tabular}{|c|c|c|}
\hline Continent/Major Region ${ }^{1}$ & Sub-Region ${ }^{1}$ & Nations * \\
\hline \multirow{5}{*}{ Africa } & North Africa & Algeria, Egypt, Libya, Morocco, Sudan (former), Tunisia, Western Sahara \\
\hline & East Africa & $\begin{array}{l}\text { Burundi, Comoros, Djibouti, Eritrea, Ethiopia, Kenya, Madagascar, } \\
\text { Malawi, Mauritius, Mayotte, Mozambique, Reunion, Rwanda, Seychelles, } \\
\text { Somalia, Uganda, United Republic of Tanzania, Zambia, Zimbabwe }\end{array}$ \\
\hline & Middle Africa & $\begin{array}{l}\text { Angola, Cameroon, Central African Republic, Chad, Congo, Democratic } \\
\text { Republic of the Congo, Equatorial Guinea, Gabon, Sao Tome and Principe }\end{array}$ \\
\hline & Southern Africa & Botswana, Lesotho, Namibia, South Africa, Swaziland/Eswatini \\
\hline & West Africa & $\begin{array}{c}\text { Benin, Burkina Faso, Cabo Verde, Code D’Ivoire, the Gambia, Ghana, } \\
\text { Guinea, Guinea Bissau, Liberia, Mali, Mauritania, Niger, Nigeria, } \\
\text { Senegal, Sierra Leone, Togo }\end{array}$ \\
\hline \multirow{8}{*}{ Asia } & West Asia & $\begin{array}{l}\text { Armenia, Azerbaijan, Bahrain, Cyprus, Georgia, Iraq, Israel, Jordan, } \\
\text { Kuwait, Lebanon, State of Palestine, Oman, Qatar, Saudi Arabia, Syrian } \\
\text { Arab Republic, Turkey, United Arab Emirates, Yemen }\end{array}$ \\
\hline & \multirow[b]{2}{*}{ South Asia } & India * \\
\hline & & $\begin{array}{l}\text { Afghanistan, Bangladesh, Bhutan, India, Iran, Maldives, Nepal, Pakistan, } \\
\text { Sri Lanka }\end{array}$ \\
\hline & South East Asia & $\begin{array}{c}\text { Brunei Darussalam, Cambodia, Indonesia, Lao Peoples Democratic } \\
\text { Republic, Malaysia, Myanmar, Philippines, Singapore, Thailand, Timor } \\
\text { Leste, Vietnam }\end{array}$ \\
\hline & \multirow[b]{2}{*}{ East Asia } & China * \\
\hline & & $\begin{array}{c}\text { Democratic People's Republic of Korea, Japan, Mongolia, Republic of } \\
\text { Korea }\end{array}$ \\
\hline & \multirow{2}{*}{ Central Asia } & Kazakhstan * \\
\hline & & Kyrgyzstan, Tajikistan, Turkmenistan, Uzbekistan \\
\hline \multirow{5}{*}{ Europe } & \multirow[b]{2}{*}{ East Europe } & Russian Federation * \\
\hline & & $\begin{array}{c}\text { Belarus, Bulgaria, Czech Republic, Hungary, Poland, Republic of } \\
\text { Moldova, Romania, Slovakia, Ukraine }\end{array}$ \\
\hline & North Europe & $\begin{array}{l}\text { Denmark, Estonia, Faroe Islands, Finland, Iceland, Ireland, Latvia, } \\
\text { Lithuania, Norway, Sweden, United Kingdom }\end{array}$ \\
\hline & South Europe & $\begin{array}{l}\text { Albania, Bosnia and Herzegovina, Croatia, Greece, Italy, Malta, } \\
\text { Montenegro, Portugal, Serbia, Slovenia, Spain, Yugoslavia }\end{array}$ \\
\hline & West Europe & $\begin{array}{c}\text { Austria, Belgium, France, Germany, Luxembourg, Netherlands, } \\
\text { Switzerland }\end{array}$ \\
\hline Oceania & Oceania & $\begin{array}{c}\text { American Samoa, Australia, Cook Islands, Fiji, French Polynesia, Guam, } \\
\text { Kiribati, Micronesia, Nauru, New Caledonia, New Zealand, Niue, Pacific } \\
\text { Islands Trust, Papua New Guinea, Samoa, Solomon Islands, Tokelau, } \\
\text { Tonga, Tuvalu, Vanuatu }\end{array}$ \\
\hline \multirow{8}{*}{ Americas } & \multirow{2}{*}{ North America } & United States * \\
\hline & & Canada * \\
\hline & & Mexico * \\
\hline & Central America & $\begin{array}{c}\text { Antigua and Barbuda, Bahamas, Barbados, Belize, Bermuda, British } \\
\text { Virgin Islands, Cayman Islands, Costa Rica, Cuba, Dominica, Dominican } \\
\text { Republic, El Salvador, Grenada, Guadeloupe, Guatemala, Haiti, } \\
\text { Honduras, Jamaica, Martinique, Montserrat, Nicaragua, Panama, } \\
\text { Trinidad and Tobago }\end{array}$ \\
\hline & \multirow{4}{*}{ South America } & Argentina * \\
\hline & & Brazil * \\
\hline & & Chile* \\
\hline & & $\begin{array}{l}\text { Bolivia, Colombia, Ecuador, French Guiana, Guyana, Paraguay, Peru, } \\
\text { Suriname, Uruguay, Venezuela }\end{array}$ \\
\hline
\end{tabular}

${ }^{1}$ Based on UN world regions, available at unstats.un.org/unsd/methodology $/ \mathrm{m} 49 / .{ }^{*}$ Livestock in nations marked with an asterisk were distributed at the sub-national level. 


\section{Results}

\subsection{Global GI and GP}

Over the 11 study years, the model-based average global grassland ANPP varied from a minimum of 4.77 to a maximum $5.16 \mathrm{Pg} \mathrm{C}$, global shrubland ANPP varied from 8.23 to 8.69 Pg C, and total rangeland ANPP from 13.0 to 14.0 Pg C (Table 3). Minimum global ANPP in grassland, shrubland, and total rangeland over the study period all occurred in 2002, while maximum values occurred in different years and did not coincide. Global total livestock requirement for grazing intake, derived as the grazing gap between estimated total intake requirements and available fodder after accounting for losses and waste, varied from 1.54 to $1.82 \mathrm{Pg} \mathrm{C}$ and increased every year of the 2000 to 2010 period (Table 3).

Table 3. Annual Global ANPP and Livestock Feed Quantities.

\begin{tabular}{|c|c|c|c|c|c|c|c|c|c|c|c|}
\hline Global Quantities ${ }^{1}$ : & 2000 & 2001 & 2002 & 2003 & 2004 & 2005 & 2006 & 2007 & 2008 & 2009 & 2010 \\
\hline Grassland ANPP $^{2}(\mathrm{Pg} \mathrm{C})$ & 5.14 & 5.01 & 4.77 & 4.83 & 5.07 & 4.92 & 5.07 & 5.05 & 5.05 & 5.06 & 5.16 \\
\hline Shrubland ANPP 2 (Pg C) & 8.81 & 8.64 & 8.23 & 8.30 & 8.42 & 8.35 & 8.68 & 8.63 & 8.69 & 8.61 & 8.65 \\
\hline Total rangeland $\mathrm{ANPP}^{2}(\mathrm{Pg} \mathrm{C})$ & 13.96 & 13.65 & 13.00 & 13.12 & 13.49 & 13.27 & 13.75 & 13.68 & 13.73 & 13.67 & 13.81 \\
\hline Fodder consumed ${ }^{3}$ & 0.86 & 0.88 & 0.87 & 0.90 & 0.93 & 0.94 & 0.94 & 0.98 & 1.00 & 0.98 & 0.99 \\
\hline Grazing ${ }^{4}$ intake required $(\mathrm{Pg} \mathrm{C})$ & 1.54 & 1.54 & 1.59 & 1.61 & 1.64 & 1.68 & 1.72 & 1.74 & 1.75 & 1.80 & 1.82 \\
\hline Grazing intake supplied (Pg C) & 1.50 & 1.50 & 1.54 & 1.57 & 1.59 & 1.63 & 1.67 & 1.69 & 1.69 & 1.73 & 1.74 \\
\hline Unmet grazing requirement ${ }^{5}(\operatorname{Pg~C})$ & 0.04 & 0.04 & 0.05 & 0.04 & 0.05 & 0.05 & 0.06 & 0.05 & 0.06 & 0.07 & 0.08 \\
\hline $\mathrm{GI}^{6}(\%)$ & 10.74 & 10.99 & 11.87 & 11.96 & 11.79 & 12.27 & 12.11 & 12.34 & 12.31 & 12.64 & 12.61 \\
\hline $\mathrm{GP}^{7}(\%)$ & 63.59 & 63.03 & 63.82 & 63.64 & 63.18 & 63.45 & 63.88 & 63.26 & 62.87 & 63.71 & 63.68 \\
\hline
\end{tabular}

${ }^{1}$ Gray shaded cells show the minimum value over the 2000-2010 period, and cells printed in bold show the maximum value over the period. ${ }^{2}$ ANPP: aboveground net primary productivity, calculated as $0.6 *$ average modeled NPP, per Fetzel et al. (2013). ${ }^{3}$ Fodder refers to any feedstuff that is harvested and delivered to animals, whether they are housed or not. Total quantities of fodder, including market feeds, hay and silage crops, and collected crop residues, minus estimates of losses and waste before consumption (see text). ${ }^{4}$ Grazing intake refers to any plant material consumed where it grew by foraging livestock, whether housed or not. Grazing requirement is derived by subtracting consumed fodder quantities from total livestock intake requirements. ${ }^{5} \mathrm{In}$ some areas, more grazing intake is required than is available, resulting in deficits. Grazing intake supplied is capped at $100 \%$ of ANPP in those areas. ${ }^{6}$ Grazing Intensity (GI) $=$ the amount of annual ANPP consumed by grazing, expressed as a percentage. It cannot exceed $100 \%$; any national deficits are recorded. ${ }^{7}$ Grazing Proportion of Intake (GP) = the amount of total annual livestock intake requirement that is supplied by grazing, expressed as a percentage. It cannot exceed $100 \%$.

In the absence of local limitations in available ANPP, these grazing requirements would result in global grazing intensities (GI) varying between $11.0 \%$ and $13.2 \%$ of total rangeland ANPP. However, because there were state- or national-level deficits between available ANPP and grazing requirements in each year of the study, actual global average GI varied from $10.7 \%$ to $12.6 \%$ of ANPP. Annual global grazing intake deficits due to insufficient national or state ANPP ranged from $33.6 \mathrm{Tg} C$ in $2000(2.4 \%$ of that year's total grazing intake requirement) to $77.8 \mathrm{Tg} \mathrm{C}$ in 2010 (4.3\% of that year's total grazing intake requirement). This pattern suggests the beginning of a divergence between ever-increasing global grazing intake requirements and variable but non-increasing rangeland ANPP (Table 3), and warrants further examination over a longer period and a major focus on future projections. The causes of variable ANPP also warrant careful examination to assess the impact of major extreme temperature and hydrological extremes such as heatwaves, droughts, floods and fires on rangelands and their productivity both in the past and future.

\subsection{Regional Patterns}

In most regions (Table 2), grazing deficits are small or nonexistent (Table 4) and GI is moderate or low (Figure 1). In regions where grazing deficits occurred, they tended to occur in many or most years (Table 4). Many of these deficits constitute small proportions of the total amount of grazing intake required (Table 4), possibly indicating errors in inventory data or land-cover/use classification. However, some regions and/or large nations consistently had unsustainable or impossible GI. 
Table 4. Sub-regional grazing intake requirements and deficits during the study period.

\begin{tabular}{|c|c|c|c|c|c|c|c|c|c|c|c|c|c|c|c|c|c|c|c|c|c|c|c|}
\hline \multirow{2}{*}{ Region } & \multirow{2}{*}{ Subregion or Nation: } & \multicolumn{11}{|c|}{ Annual Grazing Intake Requirement (Tg C/Year) ${ }^{1}$} & \multicolumn{11}{|c|}{ Annual Grazing Deficits (Tg C/Year) ${ }^{2}$} \\
\hline & & 2000 & 2001 & 2002 & 2003 & 2004 & 2005 & 2006 & 2007 & 2008 & 2009 & 2010 & 2000 & 2001 & 2002 & 2003 & 2004 & 2005 & 2006 & 2007 & 2008 & 2009 & 2010 \\
\hline \multirow{4}{*}{ Africa } & East Africa & 93.8 & 95.6 & 100.9 & 103.2 & 105.8 & 109.5 & 112.0 & 127.8 & 134.7 & 137.8 & 141.0 & 0.27 & 0.27 & 0.31 & 0.28 & 0.32 & 0.15 & 0.19 & 0.19 & 0.16 & 0.33 & 0.19 \\
\hline & Middle Africa & 17.8 & 17.9 & 17.8 & 18.2 & 18.3 & 18.7 & 19.1 & 20.0 & 19.7 & 19.8 & 19.6 & & & & & & & & & & & \\
\hline & Southern Africa & 20.7 & 21.1 & 20.1 & 20.3 & 19.8 & 19.8 & 19.5 & 20.1 & 20.2 & 20.5 & 20.6 & & & & & & & & & & & \\
\hline & West Africa & 54.2 & 56.8 & 57.4 & 59.8 & 62.0 & 62.7 & 63.8 & 68.4 & 68.7 & 74.7 & 75.3 & & 0.16 & 1.72 & 1.34 & 1.77 & 1.82 & 2.49 & 3.43 & 3.61 & 5.27 & 6.30 \\
\hline \multirow{6}{*}{ Americas } & Argentina & 31.3 & 31.9 & 35.1 & 38.0 & 39.0 & 37.3 & 38.2 & 35.9 & 36.1 & 36.9 & 24.5 & & & & & & & & & & & \\
\hline & Brazil & 185.6 & 190.5 & 200.3 & 206.5 & 215.2 & 219.7 & 216.7 & 208.7 & 205.8 & 213.6 & 215.2 & & & & & & & & & & & \\
\hline & Central America excl. Mexico & 25.0 & 25.6 & 27.5 & 27.8 & 28.3 & 29.2 & 29.5 & 30.0 & 30.3 & 30.7 & 31.4 & 0.57 & 0.52 & 0.51 & 0.48 & 0.42 & 0.42 & 0.45 & 0.43 & 0.44 & 0.46 & 0.46 \\
\hline & Mexico & 36.3 & 35.0 & 36.1 & 34.8 & 35.1 & 36.4 & 35.1 & 35.3 & 34.5 & 37.3 & 35.9 & & & & & & & & & & & \\
\hline & South America excl. Arg. \& Brazil & 112.0 & 112.5 & 112.0 & 112.7 & 113.2 & 115.7 & 115.9 & 115.3 & 116.9 & 119.4 & 118.1 & & & & & & & & & & 0.15 & \\
\hline & United States & 76.4 & 76.7 & 81.3 & 75.5 & 69.2 & 74.1 & 83.9 & 83.1 & 90.6 & 89.7 & 114.9 & & & & & & & & & & & \\
\hline \multirow{5}{*}{ E., S.E., and S. Asia } & China & 244.9 & 254.5 & 264.1 & 273.9 & 289.4 & 303.8 & 313.4 & 319.5 & 325.3 & 331.4 & 337.5 & & & & & & & & & & & \\
\hline & East Asia excl. China & 15.8 & 13.9 & 11.7 & 12.1 & 11.9 & 13.3 & 15.1 & 16.6 & 16.5 & 18.0 & 15.4 & & & & & & & & & & & \\
\hline & India & 148.2 & 149.3 & 166.4 & 156.1 & 166.0 & 167.7 & 174.0 & 171.3 & 173.2 & 180.9 & 172.3 & & & & & & & & & & & \\
\hline & South Asia excl. India & 86.4 & 89.1 & 87.8 & 88.7 & 93.9 & 94.3 & 101.0 & 100.5 & 107.2 & 108.9 & 111.8 & 29.64 & 31.35 & 33.87 & 3.55 & 31.75 & 3.33 & 38.17 & 35.34 & 4.36 & 44.43 & 44.17 \\
\hline & Southeast Asia & 51.0 & 52.7 & 56.9 & 57.0 & 56.2 & 55.4 & 56.4 & 59.6 & 58.7 & 62.1 & 61.7 & 0.16 & 0.12 & 0.53 & 0.56 & 0.55 & 0.59 & 0.64 & 0.70 & 0.76 & 0.74 & 0.83 \\
\hline \multirow{3}{*}{ W. and Ctrl. Asia } & Kazakhstan & 3.5 & 1.9 & 2.2 & 3.1 & 4.8 & 5.1 & 4.6 & 3.8 & 6.3 & 4.1 & 8.3 & & & & & & & & & & & \\
\hline & Russian Federation & 4.1 & 0.0 & 0.0 & 1.4 & 0.0 & 0.0 & 0.0 & 0.0 & 0.0 & 0.0 & 2.1 & & & & & & & & & & & \\
\hline & West Asia/Arabian Peninsula & 33.7 & 33.6 & 31.5 & 32.0 & 32.9 & 33.8 & 35.8 & 38.8 & 37.7 & 36.6 & 35.2 & 4.84 & 3.73 & 3.40 & 3.94 & 6.12 & 5.83 & 6.13 & 7.00 & 8.31 & 5.68 & 4.76 \\
\hline \multirow{4}{*}{ Europe } & $\begin{array}{l}\text { East Europe excl. Russian } \\
\text { Federation }\end{array}$ & 31.0 & 25.2 & 23.8 & 28.6 & 19.7 & 21.6 & 23.0 & 22.2 & 15.6 & 17.8 & 15.8 & & & & & & & & & & & \\
\hline & North Europe & 38.2 & 36.2 & 35.6 & 35.3 & 35.4 & 34.7 & 34.6 & 32.9 & 31.6 & 30.8 & 31.4 & & & & & & & & & & & \\
\hline & South Europe & 24.3 & 19.0 & 19.7 & 21.7 & 17.5 & 18.9 & 19.8 & 19.4 & 18.7 & 21.7 & 21.6 & 0.12 & 0.25 & 0.23 & 0.22 & 0.23 & 0.23 & 0.29 & 0.18 & 0.36 & 0.28 & 0.33 \\
\hline & West Europe & 31.6 & 30.6 & 29.3 & 33.7 & 24.1 & 26.1 & 26.8 & 25.6 & 22.6 & 23.7 & 25.4 & 1.35 & 0.42 & 0.14 & & & 0.16 & & & & & 0.29 \\
\hline \multirow{3}{*}{ Oceania } & Australia & 53.2 & 52.3 & 52.4 & 48.8 & 50.3 & 50.3 & 49.5 & 47.9 & 45.2 & 45.1 & 42.1 & & & & & & & & & & & \\
\hline & New Zealand & 21.0 & 21.0 & 21.6 & 22.0 & 22.1 & 22.2 & 22.5 & 22.2 & 21.4 & 21.8 & 21.6 & & & & & & & & & & & \\
\hline & Oceania excl. Australia and N.Z. & 1.5 & 1.6 & 1.6 & 1.6 & 1.6 & 1.6 & 1.6 & 1.7 & 1.7 & 1.7 & 1.8 & 0.17 & 0.17 & 0.18 & 0.29 & 0.28 & 0.22 & 0.23 & 0.24 & 0.25 & 0.26 & 0.26 \\
\hline
\end{tabular}

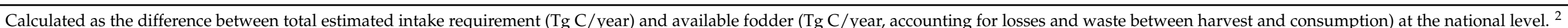

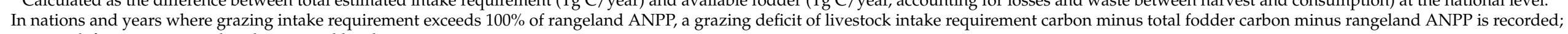
grazing deficits are summed to the regional level. 

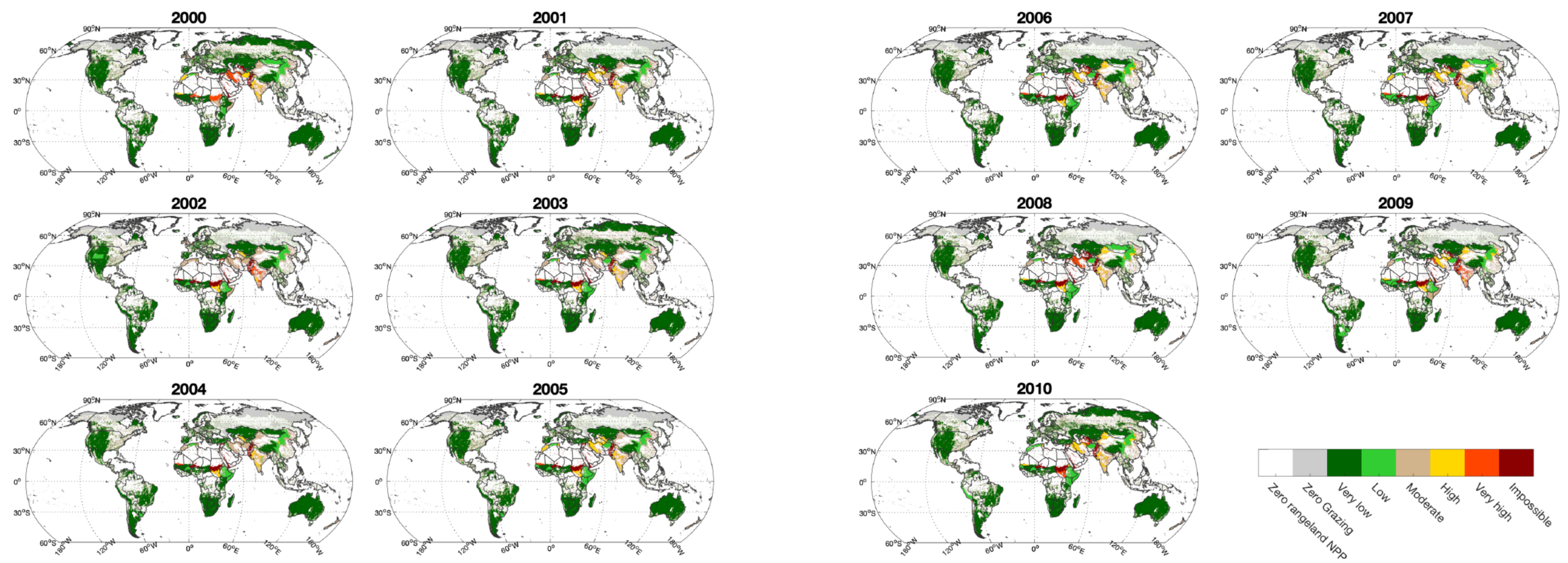

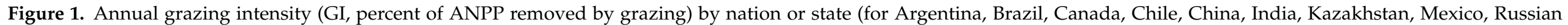

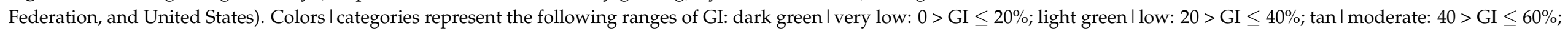
yellow I high: $60>$ GI $\leq 80 \%$; orange I very high: $80>$ GI $\leq 100 \%$; dark red I impossible: GI $\geq 100 \%$ of ANPP. 


\subsubsection{Africa}

In all but the southern region of Africa, grazing intake requirements increased during the study period (Table 4 ). GP was $\geq 72.9 \%$ in all years and sub-regions of the continent (Figure 2). In East Africa, grazing intensity increased from 7.3\% in 2000 and 2001 to $11.4 \%$ in 2009 and 2010 (Figures 1 and 2). Grazing deficits in East Africa were small both in absolute quantity and as a fraction of total grazing requirement (Table 4), and occurred only in Djibouti (Figure 1). East Africa also had the highest GPs of the continent, ranging from $91.8 \%$ to $92.8 \%$. Southern and Middle Africa exhibited uniformly low GI with no deficits.

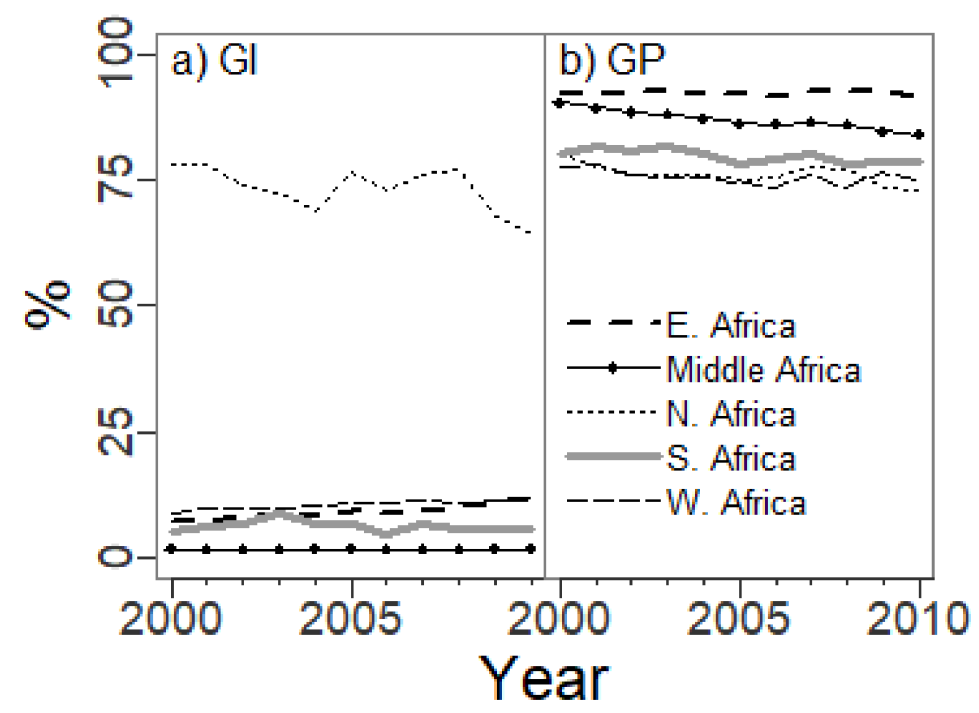

Figure 2. (a) Annual grazing intensities (GI, percent of ANPP removed by grazing) and (b) annual grazing proportion of intake (GP, percent of total livestock feed supplied by grazing, with the remainder supplied by fodder) in the sub-regions of Africa.

In North Africa, GI exceeded $64 \%$ in every year, reflecting unsustainable GI in most or all years in Libya, Morocco, the former Sudan, and Tunisia; only Algeria and Egypt exhibit sustainable GI. Large grazing deficits occurred from 2001-2010 in this region, varying from $4 \%$ to $25 \%$ of the regional grazing intake requirement and due entirely to large deficits in the former Sudan and small deficits in Libya. Both nations experienced substantial civil unrest during this period, which may have been a contributing factor. In West Africa, GI increased from $8.9 \%$ in 2000 to $12.9 \%$ in 2010 (Figure 2). Regional grazing deficits were $\leq 3 \%$ of the total grazing requirement in 2000-2005 but increased to $8.4 \%$ in 2010, due entirely to Niger, Mauritania, and Cabo Verde.

\subsubsection{The Americas}

Grazing intake requirements in Brazil and Central America and the Caribbean (excluding Mexico) increased over the study period (Table 4), but among the Americas, only Central America and the Caribbean experienced grazing deficits in most or every year of the study (Table 4). These were due exclusively to the islands of Antigua and Barbuda, Barbados, Bermuda, Grenada, Dominica, and Trinidad and Tobago. GI was high (38.6-51.2\%) in Haiti in every year of the study. A small grazing deficit (0.01\% of total grazing intake requirement) occurred in South America in 2009, due to three regions of Chile.

The U.S. had the lowest GP values of the Americas through 2009; its GP rose steeply in 2010 (Figure 3). For the entire study period, the western US, where much of the nation's grazing occurs, were experiencing a cold phase PDO and accompanying lower mean and more interannually variable ANPP [23,33]. Chen and coauthors [33] documented a jump in ANPP at a site in Colorado in 2009; ANPP at that site in 2010 was lower than in 2009 but still above average for the period. Along with increased demand for bioethanol and a $46 \%$ jump in corn grain prices [58], this may have contributed to the GP rise in 
the US in 2010. In contrast, Argentina had the second lowest GP values in the region, and its GP fell steeply in 2010. Generalized drought throughout the study period was associated with decreasing ANPP over 2001 through 2009 [59] and severe drought occurred in 2008-2010 [60]. However, decreases in cattle herd size, slaughters, production, and total stocks, along with increased conversion of pasture to soy cropland for feed [61] may have contributed to the drop in GP documented here.

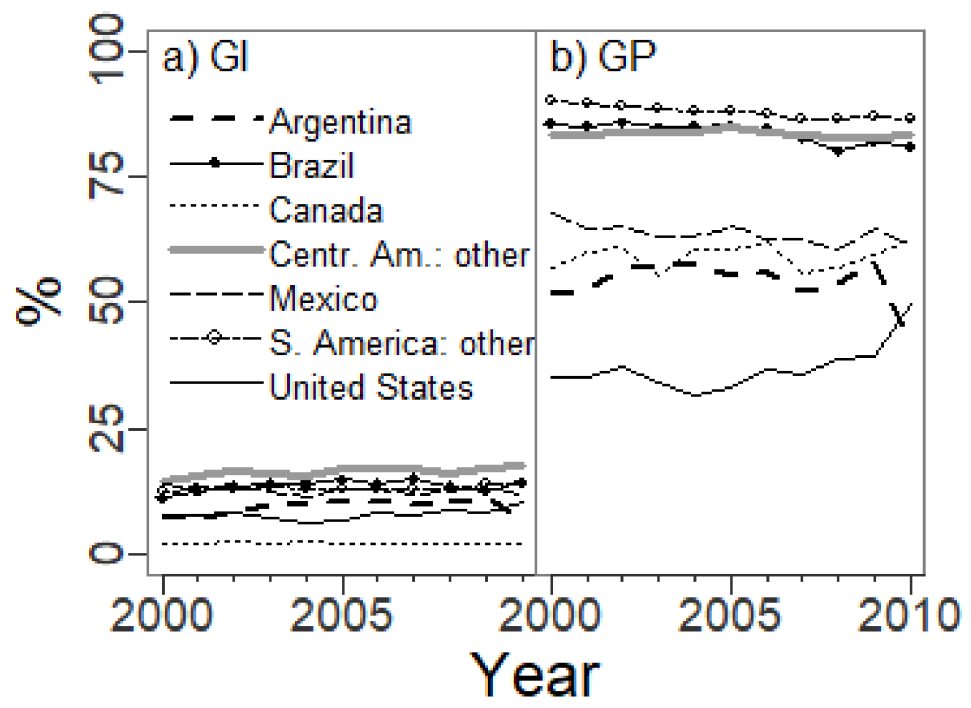

Figure 3. (a) Annual grazing intensities (GI, percent of ANPP removed by grazing) and (b) annual grazing proportion of intake (GP, percent of total livestock feed supplied by grazing, with the remainder supplied by fodder) in the sub-regions of the Americas.

\subsubsection{East, South East, and South Asia}

Grazing intake requirements increased over the study period for many parts of East, South East, and South Asia (Table 4). No grazing deficits occurred in China, although its grazing intake requirement (Table 4) and GI (Figure 4) increased steadily over the study period, and in 12 states, GI slightly exceeded $64 \%$ in 2007 and 2009. China has the highest GP values in the region (70.8\% to $74.2 \%)$ with little change over the study period, reflecting increases in consumption of both grass forage and corn, soy, and alfalfa fodders [62]. Other nations in East and South East Asia generally had lower GI and GP values than China. Minor but increasing grazing deficits $(0.02-0.13 \%$ of total grazing intake requirements) occurred each year in South East Asia due entirely to Singapore. As a small, wealthy, urbanized island nation, its deficits are likely due to inventory errors and not to actual shortages in livestock intake, because grazing cannot be widespread in that environment.

There were no grazing deficits in any years for the states in India, but India's overall GI was larger than $64 \%$ in four of the 11 study years (Figures 1 and 4 ). In a majority of India's states, GI was larger than $64 \%$ in every year (varying between $66.7-89.6 \%$ ). India was in drought in 2002-2003 and 2009 [60], and peaks in both GI and GP occur in those years. The overall GI for the other nations in South Asia were the next largest, accompanied by increasing grazing intake requirements and increasingly large grazing deficits in each year of the study. Pakistan and Afghanistan experienced severe drought in 1999-2003; while populations of sheep, goats, and cattle dipped during this period in Afghanistan, they were stable or increasing in Pakistan [10], obscuring total patterns in GI and GP for the region. The deficits in the region ranged from $32.2-40.8 \%$ of the total grazing intake requirement and were due exclusively to Pakistan. Several of the nations in this sub-region (Afghanistan, Bangladesh, Bhutan, Iran, Sri Lanka, Nepal, and Pakistan) often face geographical (arid, rugged, high elevation) and sociopolitical (war, political instability, poverty) hardships which together may explain these findings. 


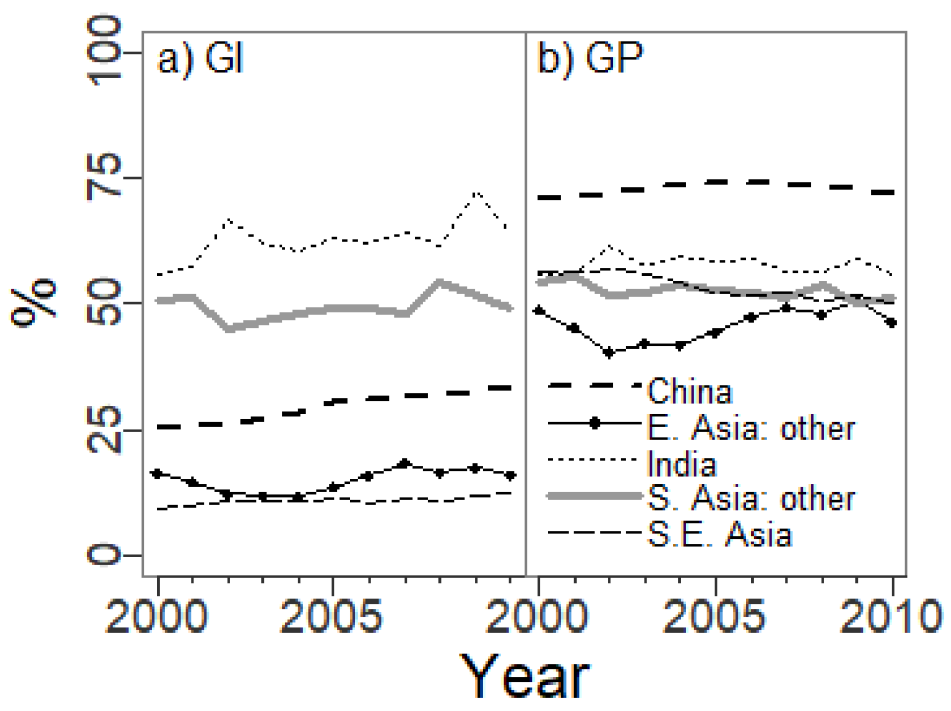

Figure 4. (a) Annual grazing intensities (GI, percent of ANPP removed by grazing) and (b) annual grazing proportion of intake (GP, percent of total livestock feed supplied by grazing, with the remainder supplied by fodder) in the sub-regions of East, South East, and South Asia.

\subsubsection{Central to West Asia and Europe}

Grazing intake requirements increased over the study period for Kazakhstan and the other nations of Central Asia (Table 4, Figure 5). In seven of the 11 study years, grazing deficits occurred in Turkmenistan and Uzbekistan, the more arid nations of this sub-region. Central Asia was in drought in 2008-2010 [60]; along with increasing requirements for grazing, drought was a likely contributor to the high GI in Central Asia in those years. In the sub-region of West Asia and the Arabian Peninsula, many of the more arid nations also experienced high or impossible GI levels with deficits in each year; only Armenia, Cyprus, Georgia, and Turkey had low GIs (below 30\%) in all years. In contrast, the Russian Federation had little or no grazing requirement during the study years (Table 4) because of abundant fodder supplies and major decreases in sheep and cattle numbers and grazing over the last century [63]. The Czech Republic and Hungary also had little or no grazing intake requirements, and most other Eastern European nations had GIs $<30 \%$ in all years.

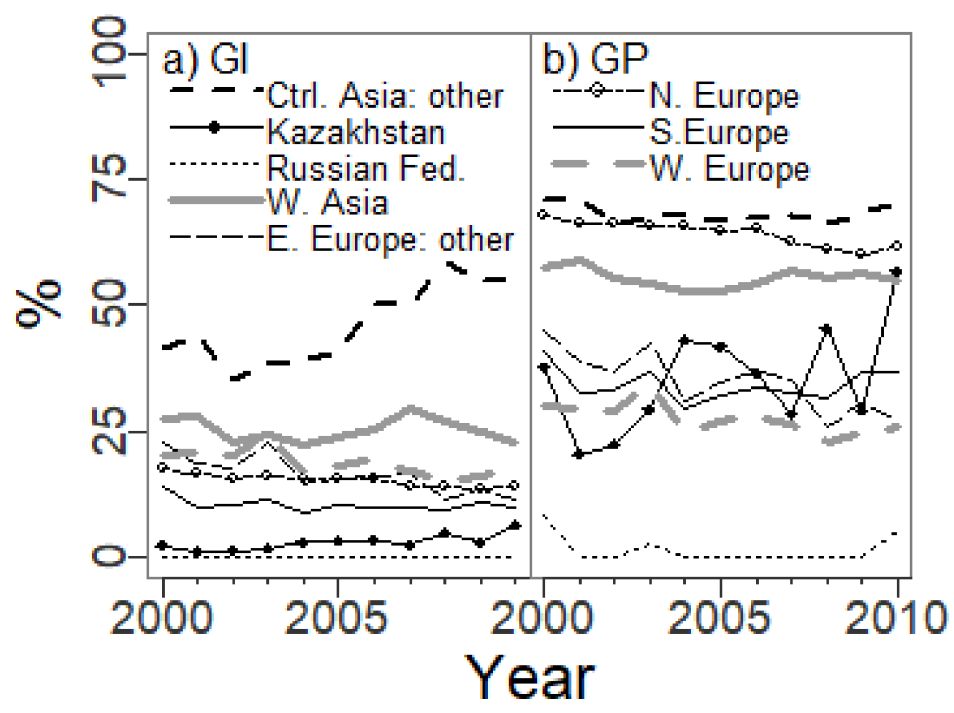

Figure 5. (a) Annual grazing intensities (GI, percent of ANPP removed by grazing) and (b) annual grazing proportion of intake (GP, percent of total livestock feed supplied by grazing, with the remainder supplied by fodder) in West and Central Asia and Europe. 
Unlike most other parts of the world, Eastern, Northern, and Western Europe demonstrated consistent decreasing trends in annual grazing intake requirements over the study period (Table 4), along with moderate decreases in GP in these regions (Figure 5). The overall populations of dairy and other cattle have decreased slightly in these sub-regions over the study period [10], and decreased grazing in the E.U. has been documented for dairy cows [64]. The drought and heatwave that occurred over Europe in the summer of 2003 is likely to be the cause of the higher GI seen in South, East, and West Europe in that year. In Northern Europe, no grazing deficits were detected; however, GIs were higher in Denmark, Ireland, and the [60] United Kingdom (15.5-55.6\%) than in the other nations in Northern Europe ( $<13.5 \%$ in all years). Nations in Southern Europe generally had low GIs in most years, but deficits occurred each year due exclusively to the island nation of Malta (Table 4). In Western Europe, deficits occurred in five of the eleven study years, due exclusively to the Netherlands. The Netherlands also had unsustainable GIs $>64 \%$ in several of the study years, as did Belgium (Figure 1).

\subsubsection{Oceania}

New Zealand's GI, varying from $39.8 \%$ to $44.6 \%$, was much higher than GIs in Australia and the smaller island nations of Oceania (Figures 1 and 6). GPs were high throughout the region. Grazing deficits ranging from 11.0 to $15.3 \%$ of total grazing requirements occurred in the island nations of Kiribati, Micronesia, Samoa, Tokelau, Tonga, Tuvalu, and Vanuatu in each year of the study. These are likely to be errors instead of true shortages, due to the small areas, partly forested cover, and small overall quantities of livestock intake needed. Australia was in severe drought starting in 2001 or earlier [65] and extending through 2010 [60]; this is a likely contributor to the high GI in Australia.

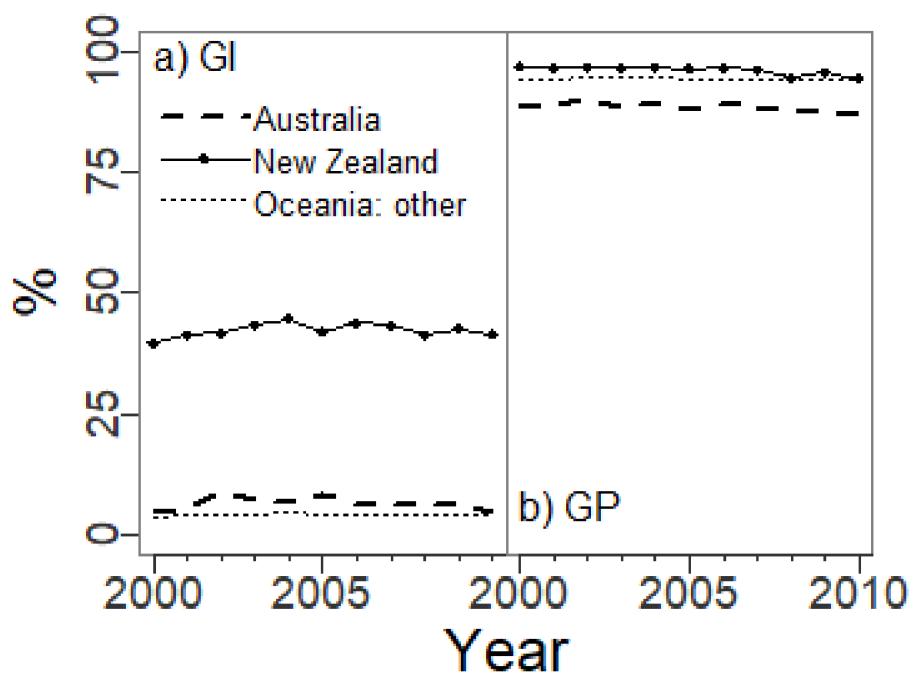

Figure 6. (a) Annual grazing intensities (GI, percent of ANPP removed by grazing) and (b) annual grazing proportion of intake (GP, percent of total livestock feed supplied by grazing, with the remainder supplied by fodder) in Oceania.

\section{Discussion}

\subsection{Global GI}

Our estimate of global GI, which was $10.7 \%$ in 2000 , is intermediate between previously reported values of $4 \%$ [53] and 15\% [30], for the year 2000. The $4 \%$ GI estimated by Petz et al. [53] includes only unmanaged grasslands, while the $15 \%$ value from Fetzel et al. [30] results from multiple approaches that do not consider multi-cropping intensity or annual changes in harvested cropland area. Whether resulting from agricultural contraction, agricultural intensification, temporary fallow, or multi-year cropland rotation, temporary managed pastures are likely to be the most productive of grazing lands, by nature of being on land that can support crops and receives fertilizer, other inputs, and 
tillage. By considering multi-cropping intensity, reconciling reported crop areas each year, and reclassifying excess MODIS cropland area as grassland, we attempt to capture this available source of forage in our analysis. Given the different details, strengths, and limitations associated with each approach, together these studies paint a more complete picture of global GI, but more research in this area is warranted given the increasing population of livestock to meet the growing demand for food.

When assessed for a limited grazing area of known extent, GI is often much higher than when assessed at the global, national, or state level, because in the former only the ANPP that has grazing livestock is considered, as opposed to the latter where all grassand shrubland within the boundary of interest is included. In between these two extremes are analyses that rely on established livestock distribution maps to constrain rangeland. Fetzel et al. [31] found that for the year 2000, GI was less than $15 \%$ on $79 \%$ of global grassland area (considered at a $0.5^{\circ}$ grid cell scale, and following the Gridded Livestock of the World distribution [66]), and they suggest that there is potential for additional grazing of dead or stored biomass on 39\% of global grasslands. Irisarri et al. [32], however, found that the GI values obtained in [31] are too low, in comparison with global GI values as well as GIs quantified for specific, well-known grazing areas calculated with different methods. Irisarri et al. [32] suggest several reasons for this underestimation, including (i) modeling NPP using only ORCHIDEE and JULES, because the former overestimates NPP in low-productivity conditions, and the latter overestimates NPP in the tropics; (ii) overestimation of ANPP as $60 \%$ of total NPP, because they consider $43 \%$ to be more accurate for grasslands and shrublands based on a global dataset of observations [67]; and (iii) errors in livestock numbers and/or rangeland area. In this study, we find a global GI even lower than $15 \%$. Nevertheless, we feel that our estimates are valid, considering that they represent consumption of ANPP from all global grasslands and shrublands, including temporary pastures on non-harvested cropland areas. Our use of the mean values from the eight ISIMIP2a models and the MOD17 product helps avoid overestimation of NPP by any single model. Because we do not impose any limits on livestock distribution and consider all grassland and shrubland within national or state boundaries, after reconciling annual harvested cropland area, errors in both rangeland area and livestock numbers and distributions should be minimum. We also considered $60 \%$ of estimated NPP to be aboveground, because we wanted to conservatively estimate where grazing deficits were truly occurring. If we instead consider ANPP to be $43 \%$ of NPP, then our calculations of national and state level GIs needed to meet grazing requirements would increase by a factor of 1.395 (i.e., $60 \% \div 43 \%$ ). However, because GI was capped at $100 \%$ and deficits recorded, regional and global summary GI must be calculated by summing production and actual grazed ANPP of the nations and states within them and then calculating percentage. Minimum and maximum values of GI over the 11-year period, calculated using both $43 \%$ and $60 \%$ of total NPP, can be compared using data presented in Table 5 . 
Table 5. Range in annual grazing intensity (GI) ${ }^{1}$ for global, regional, or large-nation areas over the 2000-2010 period.

\begin{tabular}{|c|c|c|}
\hline Area: & $\mathrm{GI}^{1}$ Based on $\mathrm{ANPP}=43 \%$ of $\mathrm{NPP}^{2}$ & GI Based on ANPP $=60 \%$ of NPP ${ }^{3}$ \\
\hline Globe & $15.4-18.4 \%$ & $11-13.2 \%$ \\
\hline Middle Africa & $2.3-2.5 \%$ & $1.7-1.8 \%$ \\
\hline North Africa & $106.5-129.6 \%$ & $76.4-92.9 \%$ \\
\hline Southern Africa & $6.6-12.2 \%$ & $4.8-8.7 \%$ \\
\hline East Africa & $10.2-16 \%$ & $7.3-11.5 \%$ \\
\hline West Africa & $12.4-18.1 \%$ & $8.9-12.9 \%$ \\
\hline West Asia and Arabian Peninsula & $36-50.6 \%$ & $25.8-36.3 \%$ \\
\hline China & $35.3-46.7 \%$ & $25.3-33.4 \%$ \\
\hline East Asia excl. China & $16.4-25.5 \%$ & $11.8-18.3 \%$ \\
\hline South East Asia & $12.9-17.7 \%$ & $9.2-12.7 \%$ \\
\hline India & $78.2-101.3 \%$ & $56.1-72.6 \%$ \\
\hline South Asia excl. India & $99.1-121.9 \%$ & $71.1-87.4 \%$ \\
\hline East Europe excl. Russian Fed. & $15.7-32 \%$ & $11.2-23 \%$ \\
\hline North Europe & $18.6-24.3 \%$ & $13.3-17.4 \%$ \\
\hline West Europe & $21.4-34.2 \%$ & $15.3-24.5 \%$ \\
\hline South Europe & $12.1-19.4 \%$ & $8.7-13.9 \%$ \\
\hline Russian Federation & $0-0.4 \%$ & $0-0.3 \%$ \\
\hline Kazakhstan & $1.8-9.1 \%$ & $1.3-6.5 \%$ \\
\hline Central Asia excl. Kazakhstan & $48.9-99.9 \%$ & $35-71.6 \%$ \\
\hline U.S. & $8.7-14.8 \%$ & $6.3-10.6 \%$ \\
\hline Canada & $2.9-3.7 \%$ & $2-2.6 \%$ \\
\hline Mexico & $15.8-19.9 \%$ & $11.3-14.3 \%$ \\
\hline Central America excl. Mexico & $20.2-24.4 \%$ & $14.5-17.5 \%$ \\
\hline Argentina & $9.3-16.3 \%$ & $6.7-11.6 \%$ \\
\hline Brazil & $15.8-21.2 \%$ & $11.3-15.2 \%$ \\
\hline South America excl. Argent., Brazil & $17.7-19.5 \%$ & $12.7-14 \%$ \\
\hline Australia & $6.3-12.2 \%$ & $4.5-8.7 \%$ \\
\hline New Zealand & $55.5-62.2 \%$ & $39.8-44.6 \%$ \\
\hline Oceania excl. Australia, N.Z. & $6.1-7.2 \%$ & $4.4-5.2 \%$ \\
\hline
\end{tabular}

${ }^{1}$ Grazing intensity (GI) = the amount of annual ANPP consumed by grazing, expressed as a percentage. It cannot exceed $100 \%$; any national deficits are recorded. ${ }^{2}$ GI calculated based on ANPP estimated as $43 \%$ of total estimated NPP. ${ }^{3}$ GI calculated based on ANPP estimated as $60 \%$ of total estimated NPP.

Despite appearing low, the global GIs documented here and in the cited studies all include significant grazing deficits. The temporal increases in these deficits that we have documented suggest that global grazing is potentially approaching its limits.

Support for this idea can be found in results from a recently developed model of rangeland grazing under different scenarios of future climate conditions [68]; this model's baseline scenario estimates that only ca. 39\% of total global rangeland NPP is herbaceous and thus readily available for grazing (as opposed to shrub or tree NPP). If we multiply our total rangeland ANPP quantities by this fraction, the global GI we found for 2010, which was $12 \%$ of total rangeland ANPP, becomes a GI of $32 \%$ of total global herbaceous ANPP. Some of this herbaceous ANPP will be on inaccessible terrain, some less palatable, and some must be left ungrazed so that plants can regenerate. For mesic rangelands, GIs between 40 and $50 \%$ of total herbaceous ANPP are suggested for sustainability, while in more prevalent semiarid rangelands [69], maximum GIs between 25 and 35\% are recommended [70]. By nature, mesic rangelands are more likely to be converted to croplands, leaving the remaining semi-arid to arid rangelands that are already approaching the upper GI limit recommended for sustainability.

Indeed, evidence of this limitation is already well documented. For example, we found Australia's national GI to vary between $4.5 \%$ and $8.7 \%$ over the study period. However, in Queensland, Australia, 17\% of annual potential NPP of semi-arid rangeland is missing due to anthropogenic land degradation, with livestock grazing the most likely cause [71]. Similarly, in this study, the U.S. has an overall relatively low GI of $6.3 \%$ to $10.6 \%$, but increasing frequency of deficit years due to climate variability may make it too risky to expand beef cattle production on rangeland [72]. Recent detailed examination of the combined effects of the PDO and ENSO on ANPP and herbivores in Colorado, USA [23], suggest, however, that the greater production and reduced variability in ANPP occur typically during warm PDO phases could be exploited with "herbivore densities above recommended levels". 


\subsection{High or Impossible Regional GIs and Grazing Deficits}

We found impossible ( $>100 \%$ of ANPP) GIs in multiple years in island and arid nations, including: Malta, Djibouti and several Sahel nations in Eastern, Northern, and Western Africa, Singapore, several island nations in the Caribbean and in Oceania, and several of the arid nations in West Asia and the Arabian Peninsula. These were mostly small deficits relative to the overall intake requirements of those nations, and can be explained by errors associated with small areas with convoluted borders such as islands, and our exclusion of grazing of ANPP on lands classified as barren or forested. However, we did find large deficits in the Netherlands and Pakistan. Among the similar studies cited above, Petz et al. [53] did not assess deficits in their analysis (GI was capped at 100\%) and included only unmanaged rangeland, but found very high GI in the Sahel, Pakistan, W. India, Middle East, North Africa, and parts of Brazil. Fetzel et al. [30] found high GI in parts of South Asia, SE Asia, and W Europe, parts of Midwest US, the Sahel, West Asia, the Middle East, and North Africa, and deficits in India, Pakistan, and Western Europe. Chang et al. (2016), using an updated version of the ORCHIDEE model and constraining many more parameters than we do here (e.g., wild herbivores, pasture area and management, and grassland area), found at least small deficits in every global region, including $2 \%$ in the Russian Federation, 2\% in West Europe, 8\% in North America, 39\% in North Africa and the Arabian Peninsula, 48\% in South Asia, 14\% in Sub-Saharan Africa, 9\% in East and South East Asia, and a $16 \%$ deficit at the global level.

In contrast to those studies, we found more modest but increasing global deficits of $2.4-4.3 \%$ of total grazing intake requirements, and no deficits (but high GI) in India, no deficits in Brazil, China, or the rest of East Asia. Over the 11 study years we found smaller deficits of $10.8-22.0 \%$ of total grazing intake requirement in the Arabian Peninsula and West Asia, $0-24.7 \%$ in North Africa, and the largest proportional deficits in South Asia excluding India, of $32.2-40.8 \%$. There are many likely reasons for these differences. The other studies all base their livestock distributions on Gridded Livestock of the World [66], in which livestock are distributed to all lands that are suitable for them. In contrast, our method starts with MODIS land cover, adjusts cropland extent annually to match our estimations of harvested area after accounting for multi-cropping, and then considers the remaining grass- and shrubland as potential grazing area for livestock. This is both a strength and a weakness of the study, yielding GI as a percent of total rangeland ANPP but consider little fine-scale spatial information beyond the total harmonized rangeland areas in each area and year.

Some areas have large amounts of on-farm harvesting or grazing of hay, silage, residues, and/or grasses, that are not captured by national agricultural surveys and then reported to or estimated by FAO. In such areas, estimates of fodder will be too low, and grazing requirements (whether on managed pasture or on unmanaged grazing lands) will be too high. Because forage and fodder are summed to obtain total intake, errors like this have a doubled effect on our findings. The Netherlands, with the highest density of livestock in the E.U. [73] is unlikely to have surplus grazable ANPP present to buffer errors or missed sources of fodder, making deficits more likely to show up year after year.

Another possible source of error comes from crop residues collected for feed. Herrero [28] states that residues are particularly important in South Asia, making up as much as $50 \%$ of livestock intake. This region is notable for overall large livestock populations, large grazing deficits in Pakistan, and high GIs throughout the region. Our estimates of residue production are based on a single global value of harvest index (the ratio of harvested biomass to total crop plant aboveground biomass) for each crop [4]. Along with harvest index, regional estimates of how much residue can be collected form our estimates of residue feed quantities in each nation. Improved crops such as recent hybrids tend to have much higher harvest index than unimproved, older varieties/landraces. What this implies is that in areas where older varieties are extensively grown, we underestimate residue production per reported unit of grain harvest. For example, if farmers in South Asia grow older, taller grain varieties in a large proportion of fields, they will have more 
residues available for feed than we would estimate, and this may help explain the high GI and grazing deficits over multiple years in such areas. Animals with inadequate intake may be underweight and survive, but we posit that this situation cannot be maintained year after year. A more rigorous assessment of these potential sources of errors is warranted.

In general, studies of livestock intake will have some errors resulting from different definitions or delineations between feed sources, but by comparing among their findings and methods, some of these errors can be better understood. For example, some studies distinguish livestock intake between grass from any source (grazing, hay crops, grain residues, managed pasture) vs. grain crops, possibly even attempting to distinguish C3 from C4 sources of intake; other distinguish multiple sources: grass, grain, 'occasional feeds', and residues (e.g., Herrero et al. [28]). In this study, we make the distinction only between intake the animal collects itself (grazing, forage) vs. intake that humans collect and deliver to animals whether housed, fenced, or free-ranging (fodder). This distinction is powerful, because the FAO provides estimates of market feeds (requiring some correcting) and proportions of residue collected for feed have been estimated at the regional level [19]. While some error is introduced by necessity when allocating these quantities at the subnational level, we believe that this information is uniquely helpful for understanding the livestock sector at the global level. Quantities and sources of fodder have changed greatly in recent years, e.g., byproducts from bioenergy crops such as distiller's grains in the US [27] and soybean cropping in Argentina [74] have both increased drastically, and both constitute large new sources of crop-based livestock fodder. Basing recent studies on static year-2000 estimates misses these large new sources of fodder.

\section{Conclusions}

The patterns of global, regional and national livestock feed intake reported in this study suggest that global rangeland has limited potential to support further expansion of the global livestock sector, which today comprises more than three times the biomass of mammals that Earth supported 100,000 years ago. To sustain the productivity and health of managed and unmanaged grazing lands, grazing resources must be managed deliberately and cautiously. Beyond livestock feed, the global grassland/rangeland are also a major component of carbon cycle and any imbalance in this component will have significant impact on this cycle.

Author Contributions: Conceptualization, G.R.A., J.W. and M.C.; methodology, J.W. and M.C.; formal analysis, J.W. and M.C.; data curation, J.W. and M.C.; writing-original draft preparation, J.W.; writing-review and editing, G.R.A. and M.C.; visualization J.W. and M.C.; supervision, G.R.A.; project administration, G.R.A.; funding acquisition, G.R.A. and M.C. All authors have read and agreed to the published version of the manuscript.

Funding: We acknowledge the financial support by National Aeronautics and Space Administration Terrestrial Ecology program under project NNH18ZDA001N (award number 80HQTR19T0055) and National Aeronautics and Space Administration Carbon Monitoring System under project NNH13AW58I.

Institutional Review Board Statement: Not applicable.

Informed Consent Statement: Not applicable.

Data Availability Statement: Data not contained within the article is available on reasonable request from the corresponding author.

Acknowledgments: The authors thank Tris West for initiating and contributing to this project, and Ben Bond-Lamberty for helpful input.

Conflicts of Interest: The authors declare no conflict of interest. 


\section{References}

1. Bar-On, Y.M.; Phillips, R.; Milo, R. The Biomass Distribution on Earth. Proc. Natl. Acad. Sci. USA 2018, 115, 6506-6511. [CrossRef]

2. Wolf, J.; Asrar, G.R.; West, T.O. Revised Methane Emissions Factors and Spatially Distributed Annual Carbon Fluxes for Global Livestock. Carbon Balance Manag. 2017, 12, 16. [CrossRef]

3. Klein Goldewijk, K.; Beusen, A.; Van Drecht, G.; De Vos, M. The HYDE 3.1 Spatially Explicit Database of Human-Induced Global Land-Use Change over the Past 12,000 Years: HYDE 3.1 Holocene Land Use. Glob. Ecol. Biogeogr. 2011, 20, 73-86. [CrossRef]

4. Wolf, J.; West, T.O.; Le Page, Y.L.; Kyle, G.P.; Zhang, X.; Collatz, G.J.; Imhoff, M.L. Biogenic Carbon Fluxes from Global Agricultural Production and Consumption. Glob. Biogeochem. Cycles 2015, 29, 1617-1639. [CrossRef]

5. Wu, D.; Piao, S.; Zhu, D.; Wang, X.; Ciais, P.; Bastos, A.; Xu, X.; Xu, W. Accelerated Terrestrial Ecosystem Carbon Turnover and Its Drivers. Glob. Chang. Biol. 2020, 26, 5052-5062. [CrossRef] [PubMed]

6. Houghton, R.A. The Worldwide Extent of Land-Use Change: In the Last Few Centuries, and Particularly in the Last Several Decades, Effects of Land-Use Change Have Become Global. BioScience 1994, 44, 305-313. [CrossRef]

7. Lambin, E.F.; Meyfroidt, P. Global Land Use Change, Economic Globalization, and the Looming Land Scarcity. Proc. Natl. Acad. Sci. USA 2011, 108, 3465-3472. [CrossRef]

8. Pongratz, J.; Dolman, H.; Don, A.; Erb, K.-H.; Fuchs, R.; Herold, M.; Jones, C.; Kuemmerle, T.; Luyssaert, S.; Meyfroidt, P.; et al. Models Meet Data: Challenges and Opportunities in Implementing Land Management in Earth System Models. Glob. Chang. Biol. 2018, 24, 1470-1487. [CrossRef] [PubMed]

9. Wolf, J. Quantifying the role of livestock in climate change. In Burleigh Dodds Series in Agricultural Science; Deryng, D., Ed.; Burleigh Dodds Science Publishing: Cambridge, UK, 2020; ISBN 978-1-78676-320-4.

10. FAO Food and Agriculture Organization of the United Nations Statistics Division (FAOSTAT). Available online: http://faostat. fao.org/ (accessed on 1 December 2015).

11. Georges, M.; Charlier, C.; Hayes, B. Harnessing Genomic Information for Livestock Improvement. Nat. Rev. Genet. 2019, 20, 135-156. [CrossRef]

12. Livestock Environmental Assessment and Performance Partnership. Environmental Performance of Feed Additives in Livestock Supply Chains_Guidelines for Assessment; FAO: Rome, Italy, 2019.

13. Thornton, P.K. Livestock Production: Recent Trends, Future Prospects. Philos. Trans. R. Soc. Lond. B Biol. Sci. 2010, 365, $2853-2867$. [CrossRef] [PubMed]

14. Klemm, T.; Briske, D.D. Retrospective Assessment of Beef Cow Numbers to Climate Variability Throughout the U.S. Great Plains. Rangel. Ecol. Manag. 2019. [CrossRef]

15. Beef Export Growth for South America I Meat \& Livestock Australia. Available online: https://www.mla.com.au/pricesmarkets / market-news/2019/beef-exports-exceptional-for-south-america/ (accessed on 29 July 2021).

16. MacDonald, J.; McBride, W. The Transformation of U.S. Livestock Agriculture: Scale, Efficiency, and Risks. In USDA Economic Research Service-EIB43. Available online: http://www.ers.usda.gov/publications/eib-economic-information-bulletin/eib43. aspx (accessed on 29 January 2014).

17. Koneswaran, G.; Nierenberg, D. Global Farm Animal Production and Global Warming: Impacting and Mitigating Climate Change. Environ. Health Perspect. 2008, 116, 578-582. [CrossRef]

18. Bouwman, A.F.; Van der Hoek, K.W.; Eickhout, B.; Soenario, I. Exploring Changes in World Ruminant Production Systems. Agric. Syst. 2005, 84, 121-153. [CrossRef]

19. Krausmann, F.; Erb, K.-H.; Gingrich, S.; Lauk, C.; Haberl, H. Global Patterns of Socioeconomic Biomass Flows in the Year 2000: A Comprehensive Assessment of Supply, Consumption and Constraints. Ecol. Econ. 2008, 65, 471-487. [CrossRef]

20. Asner, G.P.; Elmore, A.J.; Olander, L.P.; Martin, R.E.; Harris, A.T. Grazing Systems, Ecosystem Responses, and Global Change. Annu. Rev. Environ. Resour. 2004, 29, 261-299. [CrossRef]

21. Gerber, P.J.; Hristov, A.N.; Henderson, B.; Makkar, H.; Oh, J.; Lee, C.; Meinen, R.; Montes, F.; Ott, T.; Firkins, J.; et al. Technical Options for the Mitigation of Direct Methane and Nitrous Oxide Emissions from Livestock: A Review. Animal 2013, 7, 220-234. [CrossRef]

22. Smart, A.J.; Derner, J.D.; Hendrickson, J.R.; Gillen, R.L.; Dunn, B.H.; Mousel, E.M.; Johnson, P.S.; Gates, R.N.; Sedivec, K.K.; Harmoney, K.R.; et al. Effects of Grazing Pressure on Efficiency of Grazing on North American Great Plains Rangelands. Rangel. Ecol. Manag. 2010, 63, 397-406. [CrossRef]

23. Raynor, E.J.; Derner, J.D.; Hoover, D.L.; Parton, W.J.; Augustine, D.J. Large-Scale and Local Climatic Controls on Large Herbivore Productivity: Implications for Adaptive Rangeland Management. Ecol. Appl. 2020, 30, e02053. [CrossRef] [PubMed]

24. Izaurralde, R.C.; Thomson, A.M.; Morgan, J.A.; Fay, P.A.; Polley, H.W.; Hatfield, J.L. Climate Impacts on Agriculture: Implications for Forage and Rangeland Production. Agron. J. 2011, 103, 371-381. [CrossRef]

25. Hegarty, R.S. Livestock Nutrition-A Perspective on Future Needs in a Resource-Challenged Planet. Anim. Prod. Sci. 2012, 52, 406-415. [CrossRef]

26. RFA Ethanol Co-Products. Available online: http://ethanolrfa.org/resources/industry/co-products/\#1456865649440-ae77f947-7 34a (accessed on 8 November 2016).

27. USDA Economic Research Service, U.S. Bioenergy Statistics. Available online: https:/ /www.ers.usda.gov/data-products/usbioenergy-statistics/us-bioenergy-statistics/\#Coproducts (accessed on 11 October 2018). 
28. Herrero, M.; Havlík, P.; Valin, H.; Notenbaert, A.; Rufino, M.C.; Thornton, P.K.; Bluemmel, M.; Weiss, F.; Grace, D.; Obersteiner, M. Biomass Use, Production, Feed Efficiencies, and Greenhouse Gas Emissions from Global Livestock Systems. Proc. Natl. Acad. Sci. USA 2013, 110, 20888-20893. [CrossRef]

29. Chang, J.; Ciais, P.; Herrero, M.; Havlik, P.; Campioli, M.; Zhang, X.; Bai, Y.; Viovy, N.; Joiner, J.; Wang, X.; et al. Combining Livestock Production Information in a Process-Based Vegetation Model to Reconstruct the History of Grassland Management. Biogeosciences 2016, 13, 3757-3776. [CrossRef]

30. Fetzel, T.; Havlik, P.; Herrero, M.; Kaplan, J.O.; Kastner, T.; Kroisleitner, C.; Rolinski, S.; Searchinger, T.; Van Bodegom, P.M.; Wirsenius, S.; et al. Quantification of Uncertainties in Global Grazing Systems Assessment. Glob. Biogeochem. Cycles 2017, 31, 1089-1102. [CrossRef]

31. Fetzel, T.; Havlik, P.; Herrero, M.; Erb, K.-H. Seasonality Constraints to Livestock Grazing Intensity. Glob. Chang. Biol. 2017, 23, 1636-1647. [CrossRef] [PubMed]

32. Irisarri, J.G.N.; Aguiar, S.; Oesterheld, M.; Derner, J.D.; Golluscio, R.A. A Narrower Gap of Grazing Intensity. Reply to Fetzel et al., 2017. Seasonality Constrains to Livestock Grazing Intensity. Glob. Chang. Biol. 2017, 23, 3965-3966. [CrossRef] [PubMed]

33. Chen, M.; Parton, W.J.; Del Grosso, S.J.; Hartman, M.D.; Day, K.A.; Tucker, C.J.; Derner, J.D.; Knapp, A.K.; Smith, W.K.; Ojima, D.S.; et al. The Signature of Sea Surface Temperature Anomalies on the Dynamics of Semiarid Grassland Productivity. Ecosphere 2017, 8, e02069. [CrossRef]

34. IPCC. 2006 IPCC Guidelines for National Greenhouse Gas Inventories, Volume 4: Agriculture, Forestry and Other Land Use; Institute for Global Environmental Strategies: Kanagawa, Japan, 2006.

35. Ray, D.K.; Foley, J.A. Increasing Global Crop Harvest Frequency: Recent Trends and Future Directions. Environ. Res. Lett. 2013, 8, 044041. [CrossRef]

36. FAO Global Livestock Production and Health Atlas (GLiPHA). Available online: http://kids.fao.org/glipha/ (accessed on 1 January 2014).

37. USDA Quickstats 2.0. Available online: http:/ / quickstats.nass.usda.gov/ (accessed on 1 August 2019).

38. Osborn, T.W. Elemental Composition of Soybean Meal and Interlaboratory Performance. Available online: https://pubs.acs.org/ doi/pdf/10.1021/jf60210a028 (accessed on 25 June 2020).

39. Buckmaster, D. Cooperative Extension Fact Sheet Listing I-107: Forage Losses Equal Economic Losses, so Minimize Them; Penn State College of Agricultural Sciences, Agricultural and Biological Engineering: University Park, PA, USA, 1990.

40. Russelle, M. The Alfalfa Yield Gap: A Review of the Evidence. Forage Grazinglands 2013. [CrossRef]

41. Rees, D.V.H. A Discussion of Sources of Dry Matter Loss during the Process of Haymaking. J. Agric. Eng. Res. 1982, 27, 469-479. [CrossRef]

42. Idowu, J.; Grover, K.; Marsalis, M.; Lauriault, L. Circular 668: Reducing Harvest and Post-Harvest Losses of Alfalfa and Other Hay; New Mexico State University: Las Cruces, NM, USA, 2013.

43. Pepin, R. Reduce Feed Waste/Feed Shrink: Manure Management and Environmental Quality: University of Minnesota Extension. Available online: https:/ /apps.extension.umn.edu/agriculture/manure-management-and-air-quality/manure-application/ reduce-feed-waste/index.html (accessed on 24 June 2020).

44. Ishmael, W. Reduce Hay Waste I Beef Magazine. Available online: https://www.beefmagazine.com/feeding-systems/reducehay-waste (accessed on 24 June 2020).

45. Kallenbach, R. G4570 Reducing Losses When Feeding Hay to Beef Cattle I University of Missouri Extension; Forages; University of Missouri Extension: Columbia, MO, USA, 2000.

46. Carr, J. Management Practices To Reduce Expensive Feed Wastage-The Pig Site. Available online: https://web.archive.org/ web /20170425122901/http:/ / www.thepigsite.com/pigjournal/articles/2169/management-practices-to-reduce-expensivefeed-wastage/ (accessed on 24 June 2020).

47. Stockdale, C.R. Wastage of Conserved Fodder When Feeding Livestock. Anim. Prod. Sci. 2010, 50, 400-404. [CrossRef]

48. Chen, M.; Vernon, C.R.; Huang, M.; Calvin, K.V.; Kraucunas, I.P. Calibration and Analysis of the Uncertainty in Downscaling Global Land Use and Land Cover Projections from GCAM Using Demeter (v1.0.0). Geosci. Model Dev. 2019, 12, 1753-1764. [CrossRef]

49. Vernon, C.R.; Le Page, Y.; Chen, M.; Huang, M.; Calvin, K.V.; Kraucunas, I.P.; Braun, C.J. Demeter-A Land Use and Land Cover Change Disaggregation Model. J. Open Res. Softw. 2018, 6, 15. [CrossRef]

50. Friedl, M.A.; Sulla-Menashe, D.; Tan, B.; Schneider, A.; Ramankutty, N.; Sibley, A.; Huang, X. MODIS Collection 5 Global Land Cover: Algorithm Refinements and Characterization of New Datasets. Remote Sens. Environ. 2010, 114, 168-182. [CrossRef]

51. Chen, M.; Rafique, R.; Asrar, G.R.; Bond-Lamberty, B.; Ciais, P.; Zhao, F.; Reyer, C.P.O.; Ostberg, S.; Chang, J.; Ito, A.; et al. Regional Contribution to Variability and Trends of Global Gross Primary Productivity. Environ. Res. Lett. 2017, 12, 105005. [CrossRef]

52. Milchunas, D.G.; Lauenroth, W.K. Quantitative Effects of Grazing on Vegetation and Soils Over a Global Range of Environments. Ecol. Monogr. 1993, 63, 327-366. [CrossRef]

53. Petz, K.; Alkemade, R.; Bakkenes, M.; Schulp, C.J.E.; van der Velde, M.; Leemans, R. Mapping and Modelling Trade-Offs and Synergies between Grazing Intensity and Ecosystem Services in Rangelands Using Global-Scale Datasets and Models. Glob. Environ. Chang. 2014, 29, 223-234. [CrossRef]

54. Food and Agriculture Organization of the United Nations (Ed.) Transhumant Grazing Systems in Temperate Asia; Plant Production and Protection Series; Food and Agricultural Organization of the United Nations: Rome, Italy, 2003; ISBN 978-92-5-104977-8. 
55. Roy, A.K.; Singh, J.P. Grasslands in India: Problems and Perspectives for Sustaining Livestock and Rural Livelihoods. Trop. Grassl.-Forrajes Trop. 2013, 1, 240. [CrossRef]

56. USDA ERS-Major Land Uses Grassland Pasture and Range, 1945-2012, by State. Available online: https:/ /www.ers.usda.gov / data-products / major-land-uses/major-land-uses/\#Grassland\%20pasture\%20and\%20range (accessed on 30 June 2020).

57. Bohn, T.J.; Vivoni, E.R.; Mascaro, G.; White, D.D. Land and Water Use Changes in the US-Mexico Border Region, $1992-2011$. Environ. Res. Lett. 2018, 13, 114005. [CrossRef]

58. Feed Grains Custom Query. Available online: https://data.ers.usda.gov/FEED-GRAINS-custom-query.aspx (accessed on 18 August 2019).

59. Irisarri, J.G.N.; Oesterheld, M. Temporal Variation of Stocking Rate and Primary Production in the Face of Drought and Land Use Change. Agric. Syst. 2020, 178, 102750. [CrossRef]

60. Spinoni, J.; Barbosa, P.; De Jager, A.; McCormick, N.; Naumann, G.; Vogt, J.V.; Magni, D.; Masante, D.; Mazzeschi, M. A New Global Database of Meteorological Drought Events from 1951 to 2016. J. Hydrol. Reg. Stud. 2019, 22, 100593. [CrossRef]

61. USDA Foreign Agricultural Service. Annual Report: Livestock and Products Annual Argentina 2010; USDA Foreign Agricultural Service Global Agricultural Information Network: Washington DC, USA, 2010.

62. Bai, Z.; Ma, W.; Ma, L.; Velthof, G.L.; Wei, Z.; Havlík, P.; Oenema, O.; Lee, M.R.F.; Zhang, F. China's Livestock Transition: Driving Forces, Impacts, and Consequences. Sci. Adv. 2018, 4, eaar8534. [CrossRef] [PubMed]

63. Hölzel, N.; Haub, C.; Ingelfinger, M.P.; Otte, A.; Pilipenko, V.N. The Return of the Steppe Large-Scale Restoration of Degraded Land in Southern Russia during the Post-Soviet Era. J. Nat. Conserv. 2002, 10, 75-85. [CrossRef]

64. Van den Pol-van Dasselaar, A.; Hennessy, D.; Isselstein, J. Grazing of Dairy Cows in Europe-An In-Depth Analysis Based on the Perception of Grassland Experts. Sustainability 2020, 12, 1098. [CrossRef]

65. Van Dijk, A.I.J.M.; Beck, H.E.; Crosbie, R.S.; de Jeu, R.A.M.; Liu, Y.Y.; Podger, G.M.; Timbal, B.; Viney, N.R. The Millennium Drought in Southeast Australia (2001-2009): Natural and Human Causes and Implications for Water Resources, Ecosystems, Economy, and Society: Causes and Impacts of Australia's Record Drought. Water Resour. Res. 2013, 49, 1040-1057. [CrossRef]

66. Wint, G.; Robinson, T. Gridded Livestock of the World 2007; Food and Agriculture Organization: Rome, Italy, 2007 ; p. 131.

67. Scurlock, J.M.O.; Olson, R.J. NPP Multi-Biome: Grassland, Boreal Forest, and Tropical Forest Sites, 1939-1996, R1; ORNL DAAC: Oak Ridge, TN, USA, 2013. [CrossRef]

68. Boone, R.B.; Conant, R.T.; Sircely, J.; Thornton, P.K.; Herrero, M. Climate Change Impacts on Selected Global Rangeland Ecosystem Services. Glob. Chang. Biol. 2018, 24, 1382-1393. [CrossRef]

69. Booker, K.; Huntsinger, L.; Bartolome, J.W.; Sayre, N.F.; Stewart, W. What Can Ecological Science Tell Us about Opportunities for Carbon Sequestration on Arid Rangelands in the United States? Glob. Environ. Chang. 2013, 23, 240-251. [CrossRef]

70. Hudson, T.D.; Reeves, M.C.; Hall, S.A.; Yorgey, G.G.; Neibergs, J.S. Big Landscapes Meet Big Data: Informing Grazing Management in a Variable and Changing World. Rangelands 2021, 43, 17-28. [CrossRef]

71. Jackson, H.; Prince, S.D. Degradation of Net Primary Production in a Semiarid Rangeland. Biogeosciences 2016, 13, 4721-4734. [CrossRef]

72. Klemm, T.; Briske, D.D.; Reeves, M.C. Vulnerability of Rangeland Beef Cattle Production to Climate-Induced NPP Fluctuations in the US Great Plains. Glob. Chang. Biol. 2020, 26, 4841-4853. [CrossRef]

73. Agri-Environmental Indicator-Livestock Patterns. Available online: https://ec.europa.eu/eurostat/statistics-explained/index. php?title=Agri-environmental_indicator_-_livestock_patterns (accessed on 23 May 2021).

74. Lee, T.; Hansen, J.; Ash, M. Major Factors Affecting Global Soybean and Products Trade Projections; USDA Economic Research Service: Washington, DC, USA, 2016. 